\title{
Why Do Countries Peg the Way They Peg? The Determinants of Anchor Currency Choice
}

Christopher M. Meissner and Nienke Oomes

June 2006

CWPE 0643 


\title{
Why Do Countries Peg the Way They Peg? The Determinants of Anchor Currency Choice
}

\author{
Christopher M. Meissner and Nienke Oomes ${ }^{2}$
}

27 March, 2006

\begin{abstract}
Conditional on choosing a pegged exchange rate regime, what determines the currency to which countries peg or "anchor" their exchange rate? This paper aims to answer this question using a panel multinomial logit framework, covering more than 100 countries for the period 1980-1998. We find that trade network externalities are a key determinant of anchor currency choice, implying that there are multiple steady states for the distribution of anchor currencies in the international monetary system. Other factors found to be related to anchor currency choice include the symmetry of output co-movement, the currency denomination of debt, and legal or colonial origins.
\end{abstract}

JEL Classification Numbers: $\quad$ E42; F02; F33

Keywords: exchange rate regime; anchor; network externalities; optimal currency area; international currency; de facto

Authors’ E-Mail Addresses: chris.meissner@econ.cam.ac.uk; noomes@imf.org

\footnotetext{
${ }^{1}$ We would like to thank Andrew Berg, Barry Eichengreen, Jeffry Frieden, Jaewoo Lee, Paolo Mauro, Ashoka Mody, Jeromin Zettelmeyer, and participants at the Political Economy of International Finance 2004 conference, the Center for Central Banking Studies Chief Economists' Conference and an IMF seminar for useful comments. Adrian de la Garza and Young Kim provided valuable research assistance. Some of this research was conducted while Meissner was a Houblon Norman/George fellow at the Bank of England. The Bank's hospitality is appreciated. We are fully responsible for any remaining errors.

${ }^{2}$ Meissner is at the University of Cambridge, Faculty of Economics, King's College NBER. Oomes is at the International Monetary Fund. The views expressed in this working paper are those of the authors and do not necessarily represent those of the IMF or IMF policy nor those of the Bank of England.
} 


\section{INTRODUCTION}

In the past few decades, much has been written about the conditions under which countries choose, or should choose, to peg or to float. More recently, several papers have started to analyze why countries float the way they float (Hausman, Panizza, and Stein, 2001; Calvo and Reinhart, 2002). Thus far, however, little empirical work has been offered on why countries peg the way they peg. That is, while we know something about the determinants of the choice between pegs and floats, we know very little about how countries choose between different anchors for those pegs. ${ }^{3}$ And yet such knowledge is of increasing importance, as a growing number of countries are planning to establish monetary unions with common currencies that are pegged to a particular anchor. ${ }^{4}$

In light of the above, the aim of this paper is to describe the evolution of anchor choices for pegs, and to identify the factors that explain these choices. The record shows that, around 1950, countries chose from at least a half dozen anchor currencies. But strikingly, virtually all countries that have chosen to peg their currencies in some form to another currency have converged over the last fifty years to using either the U.S. dollar or the euro as anchors. Looking ahead, our results also suggest we will see an increase in the preponderance of euro pegs while dollar-based pegs and floating regimes may decline in popularity. We find that a key factor explaining these patterns is the existence of network externalities which arise because the benefits of using a particular anchor increase with the amount of trade with countries using the same anchor. As particular anchors grow in popularity, the usefulness of other options diminishes, implying a strong bandwagon or snowball effect.

Using a panel multinomial logit framework, we find the effect of network externalities to be robust to different time periods, as well as to the inclusion of various other factors that are likely to influence exchange rate regime or anchor choice. Our anchor data are derived from the de facto exchange rate regime classification recently developed by Reinhart and Rogoff (2004), and hence we follow the increasingly standard practice of avoiding the use of reported (de jure) regimes. Among the determinants of de facto regime choice per se we include standard factors such as trade and capital account openness, reserve cover, financial development, and the sensitivity to real and nominal shocks. Among the determinants of de facto anchor currency choice we include, apart from network externalities, the symmetry of shocks and the currency denomination of debt, as well as the level and variability of past inflation in the anchor-currency issuing country.

Our finding that network externalities are an important determinant of anchor currency choice implies that aggregate regime choice may be nonlinear in the number of adherents, giving rise to possible multiple steady states. This implies that the choices of a small number of countries can have large effects on the geography of the international monetary system, something which should be taken into account when advising a country on its appropriate exchange rate regime. ${ }^{5}$ Because of initial,

\footnotetext{
${ }^{3}$ There is an extensive literature of econometric studies on pegs versus floats. Previous work, of a relatively recent vintage, includes, but is not limited to: Dreyer (1978); Heller (1978); Holden, Holden, and Suss (1979); Cuddington and Otoo (1990); Savvides (1990); Edwards (1996); Bernhard and Leblang (1999); Bayoumi and Eichengreen (1997, 1999); Rizzo (1998); Frieden, Ghezzi, and Stein, (2000); Masson (2001); Poirson (2001); Juhn and Mauro (2002) Alesina and Wagner (2003).

${ }^{4}$ In the middle east, the six members of the Cooperation Council for the Arab States of the Gulf (Bahrain, Kuwait, Oman, Qatar, Saudi Arabia, and the United Arab Emirates) plan to establish a common currency pegged to the U.S. dollar by 2010 (Fasano and Schaechter, 2003). In East Asia, there are ongoing discussions about a single Asian currency. In Africa, five West African countries (Nigeria, Ghana, Guinea, Sierra Leone, and The Gambia) are close to establishing a monetary union, which will be either pegged to the euro (and thereby to the CFA-franc zone) or to the U.S. dollar. Moreover, the Southern African Development Community (SADC) aims to establish a common currency by 2018, and the African Union has seriously considered the idea of adopting a single continental currency, which Yehoue (2005) argues should be pegged to the euro. For more on African monetary unions, see Masson and Pattillo (2001) and Yehoue (2004, 2005).

${ }^{5}$ If the transaction costs associated with exchange rate volatility decrease trade, as a batch of recent research cited in Frankel's (2003) survey suggests, then the geography of the international monetary system in turn will affect the size and direction of global trade and investment flows. Klein and Shambaugh (forthcoming) show
} 
possibly random or idiosyncratic conditions prevailing in one important country, a group of countries may lock into using a particular exchange rate anchor, and may stick with this anchor even when it later might become optimal for some portion of the group to collectively use another anchor instead (or switch to a floating regime). For example, East Asian countries have mainly chosen the dollar as their anchor, while in the future it may be preferable for them, because of increasing regional integration, to form a Yen bloc, or perhaps a bloc based on a basket of east Asian currencies. Another example of a possible coordination failure is the popularity of U.S. dollar anchors in many former Soviet Union countries, most of which trade more with the euro area than with the United States, and therefore might benefit from a coordinated switch from a dollar to a euro anchor. Our results also imply that once a few important countries let go of the U.S. dollar anchor (e.g., because of fears that the U.S. current account deficit may be unsustainable), their trade partners could do the same and, hence, the dollar bloc could rapidly unravel. ${ }^{6}$

We begin this paper by describing the historical evolution of anchor choice. We then discuss the relation between network externalities, multiple steady states, and path dependence. Next, we list the others factors - besides network externalities - that could affect the choice of anchor currency and of exchange rate regime, and that we include as control variables in our regressions. We then present our empirical methodology and results. Last, we provide an estimate of the strength of network externalities and also consider a forecast for the long-run evolution of various exchange rate regimes and anchor popularity. We conclude by summarizing and discussing the policy implications of our findings.

\section{The Evolution of AnCHOR CuRREnCy ChOICE}

\section{A. Measuring Anchor Currency Choice}

In order to determine when countries use a certain anchor currency for their exchange rate regime, and which anchor they use, we use newly available data from Reinhart and Rogoff's (2004) de facto ("natural") exchange rate regime classification.

A stream of recent research has highlighted that the exchange rate regime a country claims to follow (as reported in the IMF's Annual Report on Exchange Arrangements and Exchange Restrictions) often differs from the regime actually in place. In recognition of this fact, several de facto exchange rate regime classifications have been developed as an alternative to the IMF's de jure classification (e.g., Ghosh, Gulde, Ostry, and Wolf, 1997; Bubula and Ötker-Robe, 2002; LevyYeyati and Sturzenegger, 2003; Reinhart and Rogoff, 2004). ${ }^{7}$

We choose to use the Reinhart-Rogoff (henceforth RR) classification largely because it is the only de facto classification that contains easily accessible information on anchor currencies. That is, if a country is classified as having a pegged exchange rate regime, the "chronologies" of the RRclassification describe to which currency a country pegs. To our knowledge, this dataset is the first to present this information in a systematic way for de facto pegs. ${ }^{8}$ We undertook the electronic coding of anchor currency choice based on the written descriptions included in the working paper version of Reinhart and Rogoff. Appendix I explains in more detail how the de facto anchor was determined.

explicitly that anchor choice affects the direction of global trade, and they also suggest the total amount of international trade would significantly decline if all countries discontinued pegging their exchange rates.

${ }^{6}$ Our main interest in this paper lies in explaining anchor currency choice and aggregate regime choice. If a currency is a popular anchor, it is likely to also be an "international currency." However, we do not aim to discuss the determinants of international currency choice, the demand for reserves denominated in a particular currency, or the incidence of invoicing in a currency, all of which depend on other factors besides anchor popularity.

${ }^{7}$ The IMF itself also moved to a de facto classification system in 1999, the details of which are reported in IMF (1999).

${ }^{8}$ While the IMF de jure classification does contain information on anchor currencies, we decided not to use this classification since it classifies many de facto pegs as intermediate regimes or floats, and therefore contains much less information on anchor currency choice. 
In addition, the RR classification has three other advantages over other de facto regime classifications. First, the RR classification is the most longitudinally complete data set, and allows us to follow the experience of over 150 countries over more than 40 years. Second, Reinhart and Rogoff use information on parallel market exchange rates, where appropriate, to determine the actual (de facto) rather than the stated (de jure) exchange rate policy. Finally, the RR classification distinguishes a "freely falling" category. This is important because the "free falls" are usually associated with financial crises, hyperinflations or the exit from an unsustainable peg. Including such episodes in the floating category could potentially confound the determinants of an actual float.

Like other de facto classifications, the RR classification distinguishes between different degrees of "hardness" of pegs, depending on whether the volatility of bilateral exchange rates is below a certain threshold. ${ }^{9}$ Appendix I summarizes the algorithm used to determine these different types of pegs (e.g., currency boards, pre-announced pegs, de facto pegs, crawling pegs, and crawling bands).

For our purposes, we define "pegs" as anything from a moving band that is narrower than $+/$ two percent to a country with no separate legal tender currency (i.e., anything from category 1 through 11 in Table A1 in Appendix 1). ${ }^{10}$ We define "floats" as consisting of either managed floating or freely floating regimes. Following Reinhart and Rogoff (2004), we also include "freely falling regimes" as a separate category distinct from floating and pegging.

\section{B. Stylized Facts on Anchor Currency Choice}

In this section, we present some stylized facts on anchor currency choice that emerge from studying the Reinhart-Rogoff dataset on anchor currencies mentioned above.

Figure 1 shows that the main stylized fact is that virtually all countries that have chosen to peg their exchange rates in some way to another currency have converged over the last fifty years to using either the U.S. dollar or the euro as their anchor currency (Figure 1). Between 1940 and 1950, the British pound was the most popular anchor currency, followed by the U.S. dollar and the French franc. However, there was also a substantial "other" category, which included the Japanese yen, the Dutch guilder, the Belgian franc, and the Indian rupee. (Most of these were associated with colonization or occupation during World War II). Surprisingly, there has been no Japanese yen bloc. For example, Camdessus (1995: 1-2) noted that " $[t]$ he role of the yen is not commensurate with the relative size of the Japanese economy or with Japan's emergence as the world's largest creditor country." One possibility is that Japan had a de facto U.S. dollar anchor from 1949-1977 which simply promoted the use of the U.S. dollar in Asia. ${ }^{11}$ According to Tavlas and Ozeki (1992: 4), one

\footnotetext{
${ }^{9}$ A criticism of this methodology is that exchange rates may appear "pegged" due to the mere absence or symmetry of shocks, rather than due to a policy intention to peg the exchange rate. However, if an exchange rate consistently appears to be pegged (or anchored) to one currency, but not to another, one may ask whether this absence of variability is really a coincidence or whether there is an unobservable policy being followed. Moreover, if it were the case that there were no intentional policy and our results were consistent with an optimal currency area line of argument, then we might argue that there would be little economic loss in making the exchange rate arrangement more formal through an announced peg or similar.

${ }^{10}$ As part of our robustness checks, we eliminated the countries with a fine classification between 9 and 11 from our pegs. That is, we no longer considered wide crawling bands, de facto crawling bands, and moving bands as "pegs."

${ }^{11}$ Japan maintained a parity of 1 U.S. dollar = 360 yen from April 1949 to August 1971. One reason why Japan preferred the U.S. dollar to the British pound was that U.S. economic aid during the reconstruction period and the windfall demands of the Korean war promoted dollar transactions, while sterling had the disadvantage of nonconvertibility. Thereafter, the dollar stabilized its position as the key currency for Japan, because trade in dollars also increased its share in the Asian region, and trade finance in the New York money market became more important (Iwami, 1995).
} 
reason that inhibited the use of the yen as an international currency is that the Tokyo financial market was tightly regulated until the end of the 1980s.

Between 1945 and 1972, the U.S. dollar was the most popular anchor currency chosen by developed countries, followed by the British pound and the German mark (Figure 2). Following the collapse of Bretton Woods, the anchor currency distribution among developed economies changed considerably with the U.S. dollar declining significantly in popularity, and the British pound disappearing entirely from the menu of anchor choices. While the breakup of Bretton Woods did give rise to an increased number of free and managed floaters, the majority of developed countries ended up tying their currency in some form to the German mark, and later the euro. The increased popularity of the German mark is obviously related to the exchange rate mechanism (ERM) leading up to the introduction of the euro. However, this does not yet explain why it was the German mark, rather than for example the French franc, that was chosen as an anchor currency in the ERM.

For developing countries (Figure 3), the predominant anchor currencies between 1940 and 1972 were the U.S. dollar, the British pound, and the French franc, with the latter choices largely being determined by colonial history and the consequent economic relationships. Following the collapse of Bretton Woods, developing countries followed advanced countries in that they abandoned the British pound as an anchor. However, whereas advanced countries replaced the pound for the German mark, developing countries largely switched to using the U.S. dollar as their anchor, except the group of former French colonies that continued to peg to the French franc. The only (nontransition) developing countries that adopted a German mark anchor were Malta (1978-1998) and Turkey (1998).

Following the breakup of the Soviet Union in the early 1990s, and the associated price liberalizations and hyperinflations, most transition economies ended up in the "freely falling" category for several years. They then increasingly started pegging their currencies, either tightly or loosely, to the currencies of countries with credible monetary policies, notably the German mark and the U.S. dollar. Figure 4 shows that the choice of anchor currency was curiously divided among regional lines: while Central and Eastern European countries chose to anchor to the German mark (later the euro), most former Soviet Union republics chose the U.S. dollar as anchor currency (with the exception of Estonia, which adopted a currency board arrangement with the German mark; and Latvia, which chose the SDR). By 2001, seven transition countries were anchored to the euro, eight countries (all CIS) were anchored to the U.S. dollar, one country (Latvia) was pegged to the SDR, five were freely floating, and two were freely falling. ${ }^{12}$

\section{Network Externalities, Multiple Steady States, And Path DePendence}

In this section we discuss the importance of trade network externalities (i.e., the importance of trade partners' anchor currency choices) for anchor currency choice. We first show why network externalities arise naturally in the context of anchor currency choice; then we show that network externalities can lead to multiple equilibria; and finally, we show why multiple equilibria (or rather, multiple steady states) imply path dependence (and why path dependence implies the possibility of coordination failure). Other determinants of anchor currency choice, and regime choice in general, are discussed in the next section.

\section{A. Why anchor currency choice is subject to network externalities}

According to Optimal Currency Area (OCA) theory, an important determinant of whether a country is part of an optimal currency area is the potential reduction in transaction costs. Thus, it is "optimal" for a country to adopt a given currency if, ceteris paribus, the transaction costs involved in

\footnotetext{
${ }^{12}$ The reduction in the number of transition countries during 1996-1999, which is evident from Figure 4, is due to missing parallel market information for Russia, Ukraine, and Turkmenistan.
} 
using this currency are less than the transaction costs involved in using other currencies. These transaction costs might include the costs associated with exchanging currencies (as measured by the bid-ask spread), the costs associated with lost trade due to exchange rate uncertainty, and the costs associated with hedging to avoid exchange rate risk.

Extending OCA theory to the theory of "optimal anchor choice" (OAC), we argue that a country chooses to peg to a given anchor currency (conditional on the choice to peg) so as to minimize the transaction costs associated with pegging to this currency. Moreover, since transaction costs increase with exchange rate volatility, an equivalent way of putting this is that it is "optimal" for a country to adopt the anchor currency that minimizes the sum of bilateral exchange rate volatilities, weighted by the importance of each trade partner. ${ }^{13}$

Since bilateral exchange rate volatility depends on the anchor currency choices of a country's trade partners, one country's optimal anchor choice is naturally a function of other country's anchor choices. In other words, the transaction cost saving property of pegged exchange rate regimes gives rise to network externalities (or strategic complementarities) in anchor choice.

The notion of network externalities in currency choice is not entirely new. For example, OCA theory itself states that the transaction cost savings associated with using a particular currency increase with the share of transactions carried out in that currency. The same assumption is made in the literature following Kiyotaki and Wright (1989), and in a more recent sizeable literature, including Dowd and Greenaway (1993), Flandreau (1996), Eichengreen and Flandreau (1998), and Meissner (2005), which demonstrates how these types of externalities matter for monetary regimes. Similarly, in the related literature on international currency use, Swoboda (1968) and Krugman (1984) have emphasized the existence of "economies of scale," and Tavlas and Ozeki (1992) argued that a condition that reinforces international currency use is "the amount of trade invoiced in a currency."

\section{B. Why network externalities imply multiple equilibria}

It is straightforward to show that network externalities give rise to multiple equilibria. We do this by considering a simple two-currency model. ${ }^{14}$ Suppose that the world consists of only two countries, $i$ and $j$, and each country has a choice between two anchor currencies: the U.S. dollar (\$), and the euro (€). The payoffs $\left(U_{i}, U_{j}\right)$ associated with each anchor currency choice are given in Table 1. These payoffs are a negative function of transaction costs.

Table 1. Payoff matrix

\begin{tabular}{|c|c|c|}
\hline & $\boldsymbol{A}_{j}=\mathbf{\$}$ & $\boldsymbol{A}_{j}=\mathbf{€}$ \\
\hline $\boldsymbol{A}_{i}=\mathbf{\$}$ & 1,1 & 0,0 \\
\hline $\boldsymbol{A}_{i}=\boldsymbol{€}$ & 0,0 & 1,1 \\
\hline
\end{tabular}

When the two countries each choose a different anchor currency, they both face transaction costs that depend on the bilateral exchange rate volatility between the euro and the dollar. We normalize the payoffs associated with this volatility to zero. When the two countries both adopt the same anchor currency, they are able to reduce this bilateral exchange rate volatility (and hence transaction costs). The optimal strategy, or best response, for country $i$ is therefore $A_{\mathrm{i}}=A_{j}$, and the

\footnotetext{
${ }^{13}$ The transaction costs associated with exchanging currencies (bid-ask spread) are zero only in the case of currency unions, when the anchor currency is legal tender (or when it is illegally used as means of payment in underground economies). For all other types of pegs, the bid-ask spread is likely to increase with exchange rate volatility, as banks or exchange offices face higher exchange rate risk when the exchange rate is more volatile.

${ }^{14}$ We will generalize this to multiple anchor currencies in further research.
} 
best response for country $j$ is $A_{\mathrm{j}}=A_{i}$. This implies two Nash equilibria in pure strategies: one where both countries adopt the dollar, and one where both adopt the euro as their anchor.

Now suppose that each country in fact has multiple trade partners, where the share of each trade partner in total trade is denoted by $t_{i j}=T_{i j} / T_{i}$, with $T_{i j}$ denoting the total amount of trade between countries $i$ and $j$, and $T_{i}$ denoting the total amount of trade between country $i$ and the rest of the world. For simplicity, we assume that all positive bilateral exchange rate volatilities generate zero payoffs (this assumption can be generalized later), and that zero bilateral exchange rate volatility (i.e., adopting the same anchor as a trade partners) generates payoffs equal to $1 / J$, where $J$ is the number of trade partners. This implies that the payoff to country $i$ of adopting a given anchor currency increases in the number of countries that adopt the same anchor currency, and these payoffs equal one if all trade partners adopt the same anchor.

Alternatively, the trade share $t_{i j}$ can be interpreted as the probability that the next international transaction between country $i$ and the rest of the world takes place with country $j$. The expected payoff of adopting an anchor currency $A_{i}$ is then:

$$
U_{i}\left(A_{i}\right)=\sum_{j=1}^{J} t_{i j} U_{i}\left(A_{i}, A_{j}\right) .
$$

Since we assume, for now, that $U_{i}\left(A_{i}, A_{j}\right)=0, \forall i \neq j$, this can be alternatively written as

$$
U_{i}\left(A_{i}\right)=\sum_{j=1}^{J} t_{i j} I\left(A_{j}=A_{i}\right)
$$

where $I\left(A_{j}=A_{i}\right)$ is an indicator function that equals one when $j$ adopts the same anchor currency as $i$, and zero otherwise. Thus, the payoff for country $i$ associated with using anchor currency $A$ is simply the weighted average (weighted by trade shares) of the number of trade partners that use this same anchor currency. In particular,

$$
U_{i}(\$)=\sum_{j=1}^{J} t_{i j} I\left(A_{j}=\$\right)=\operatorname{Pr}\left(A_{j}=\$\right) \equiv p_{j}(\$),
$$

that is, the payoff for country $i$ of anchoring to the dollar equals the share of $i$ 's trade that takes place with dollar-anchoring countries. In terms of our two-country game this trade share can be interpreted as the probability that the "representative trade partner" is anchored to the dollar. Similarly, we can write

$$
U_{i}(€)=\sum_{j=1}^{J} t_{i j} I\left(A_{j}=€\right)=\operatorname{Pr}\left(A_{j}=€\right) \equiv 1-p_{j}(\$),
$$

In a deterministic model, i.e., without any idiosyncratic shocks, the best response for country $i$ then can be written as follows:

$$
p_{i}(\$)\left\{\begin{array}{cc}
=0 & \text { if } p_{j}(\$)<0.5 \\
\in[0,1] & \text { if } p_{j}(\$)=0.5 \\
=1 & \text { if } p_{j}(\$)>0.5
\end{array}\right.
$$

This best response correspondence is illustrated in Figure 5. It implies that country $i$ will choose to anchor to the dollar if there is more than a 50 percent chance that the representative trade partner $j$ will anchor to the dollar as well, i.e., if more than half of its trade partners are anchored to the dollar (the "dollar bloc"). Conversely, country $i$ will anchor to the euro if the representative trade partner $j$ is most likely to anchor to the euro, i.e., if the majority of trade partners are anchored to the "euro bloc". When exactly half of its trade is with the dollar bloc, and half of its trade with the euro bloc, country $i$ is indifferent between the two anchor currencies and chooses an anchor at random. 


\section{Proposition 1: Equilibria of the deterministic anchor choice model (Figure 5)}

Suppose that all countries are identical except for their trade shares (i.e., there are no other determinants of anchor currency choice besides trade network externalities). Then,

(a) there exist three symmetric Nash equilibria, one with all countries pegging to the dollar, one with all countries pegging to the euro, and one with all countries randomizing between dollar and euro (resulting in half the world pegging to the dollar and half the world pegging to the euro);

(b) asymmetric Nash equilibria can exist only when the world is split into two or more separate trade blocs (closed subsets), so that within each bloc, all countries trade with each other, but there is no trade between any two countries from different blocs.

\section{Proof:}

(a) In a symmetric Nash equilibrium, $p_{i}(\$)=p_{j}(\$)=p(\$)$. Suppose all countries except $i$ are pegged to the dollar. Then country $i$ 's best response is to peg to the dollar as well, i.e., $p(\$)=1$ is a Nash equilibrium. Similarly, when all trade partners of $i$ are pegged to the euro, $i$ 's best response is to peg to the euro as well, i.e., $p(\$)=0$ is a Nash equilibrium. Finally, suppose all countries randomize between pegging to the dollar and pegging to the euro. Then the expected share of the dollar bloc is 50 percent independently of trade patterns, hence, under rational expectations, the best response is to randomize between dollar and euro, i.e., $p(\$)=0.5$ is a Nash equilibrium.

(b) Since there is no trade between the trade blocs, it follows from (a) that it is possible for each trade bloc to settle on a different symmetric Nash equilibrium (different currency blocs).

Next, consider the more general, non-deterministic case with idiosyncratic preferences $\varepsilon_{i}\left(A_{i}\right)$. We can then write

$$
\begin{aligned}
& U_{i}(\$)=p_{j}(\$)+\mu \varepsilon_{i}(\$) \\
& U_{i}(€)=p_{j}(€)+\mu \varepsilon_{i}(€),
\end{aligned}
$$

where $\mu$ is a parameter to denote the relative importance of idiosyncratic preferences.

This gives the following best response function:

$$
\begin{aligned}
p_{i}(\$) & =\operatorname{Pr}\left(p_{j}(\$)+\mu \varepsilon_{i}(\$)>p_{j}(€)+\mu \varepsilon_{i}(€)\right) \\
& =\operatorname{Pr}\left(\varepsilon_{i}(\$)-\varepsilon_{i}(€)<-\frac{1}{\mu}\left[p_{j}(\$)-p_{j}(€)\right]\right) \\
& =\operatorname{Pr}\left(\varepsilon_{i}(\$)-\varepsilon_{i}(€)<-\frac{2}{\mu}\left[p_{j}(\$)-0.5\right]\right)
\end{aligned}
$$

where the last equation results from the fact that $p_{j}(€)=1-p_{j}(\$)$.

Note that, for $\mu=0$, this equation reduces to the best response correspondence given above.

A standard assumption in discrete choice models is that the idiosyncratic term is a random variable which is exponentially distributed. This gives a logit model:

$$
p_{i}(\$)=\frac{1}{1+e^{-\frac{1}{\mu}\left[p_{j}(\$)-p_{j}(\epsilon)\right]}}=\frac{1}{1+e^{-\frac{2}{\mu}\left[p_{j}(\$)-0.5\right]}},
$$

For $\mu \rightarrow 0$, the best response correspondence reduces to that of the deterministic model (without idiosyncratic preferences).

\section{Proposition 2: Equilibria of the stochastic anchor choice model (Figure 6)}


Suppose that all countries are identical except for sensitivity to trade network externalities. Defining a symmetric equilibrium as $\left(p_{i}(\$)=p_{j}(\$)=p(\$)\right)$, we hold that:

(a) for $\mu>0.5$, there exists a unique symmetric Nash equilibrium, with $p(\$)=0.5$

(b) for $\mu<0.5$, there exist two additional symmetric Nash equilibria: one equilibrium where the majority of countries are pegging to the dollar, i.e., $p(\$)>0.5$, and one equilibrium where the majority of countries are pegging to the euro, i.e., $p(\$)<0.5$.

Proof: It can easily be verified that $p(\$)=0.5$ is always an equilibrium, and that, for $\mu=0.5$, the slope of the best response function in this equilibrium equals unity, i.e., $p_{i}^{\prime}(\$)=1$ at $p_{i}(\$)=0.5$. For $\mu>0.5$, the slope is less than unity, i.e., $p_{i}^{\prime}(\$)<1$ at $p_{i}(\$)=0.5$, which implies that there is a unique symmetric equilibrium. For $\mu<0.5$, the slope exceeds unity, which implies the existence of three symmetric equilibria. We omit a formal proof here, which is given in Oomes (2003b), and instead illustrate this proposition in Figure $6 .{ }^{15}$

The best response functions and equilibria of the stochastic model are illustrated in Figure 6 for various values of $\mu$. Intuitively, when $\mu$ is relatively small, idiosyncratic factors are not very important, and hence the model is similar to the deterministic model, where network externalities are the only determinants of anchor currency choice, and generate three symmetric equilibria. However, when $\mu$ is large, idiosyncratic factors start to play a more important role than network externalities, and therefore the multiple equilibria disappear.

\section{General payoffs}

We now consider the case with general payoffs $U_{i}\left(A_{i}, A_{j}\right)$ and $U_{j}\left(A_{i}, A_{j}\right)$ and idiosyncratic preferences. For simplicity we still assume that there are only two anchor currencies (this could be generalized to $n$ anchor currencies).

Table 2. General payoff matrix

\begin{tabular}{|c|c|c|}
\hline & $\boldsymbol{A}_{j}=\mathbf{\$}$ & $\boldsymbol{A}_{j}=\mathbf{€}$ \\
\hline $\boldsymbol{A}_{\boldsymbol{i}}=\mathbf{\$}$ & $U_{i}(\$, \$), U_{j}(\$, \$)$ & $U_{i}(\$, €), U_{j}(\$, €)$ \\
\hline $\boldsymbol{A}_{\boldsymbol{i}}=\mathbf{€}$ & $U_{i}(€, \$), U_{j}(€, \$)$ & $U_{i}(€, €), U_{j}(€, €)$ \\
\hline
\end{tabular}

In this case, the best response function generalizes to

$$
p_{i}(\$)=\frac{e^{U_{i}(\$)}}{e^{U_{i}(\$)}+e^{U_{i}(€)}}=\frac{1}{1+e^{U_{i}(€)-U_{i}(\$)}}
$$

with

$$
\begin{gathered}
U_{i}(\$)=p_{j}(\$) U_{i}(\$, \$)+p_{j}(€) U_{i}(\$, €)+\mu \varepsilon_{i}(\$) \\
U_{i}(€)=p_{j}(\$) U_{i}(€, \$)+p_{j}(€) U_{i}(€, €)+\mu \varepsilon_{i}(€) \\
U_{i}(\$)-U_{i}(€)=p_{j}(\$)\left[U_{i}(\$, \$)-U_{i}(€, \$)\right]+p_{j}(€)\left[U_{i}(\$, €)-U_{i}(€, €)\right]+\mu\left[\varepsilon_{i}(\$)-\varepsilon_{i}(€)\right]
\end{gathered}
$$

\footnotetext{
${ }^{15}$ Oomes (2003b), also shows that it is possible for asymmetric equilibria to exist for local trade networks, where every country trades only with its neighbors, but is indirectly able to trade with any other country. In addition, Oomes (2003b) suggests that the threshold value of $\mu$ depends on the extent of home bias, or trade openness: for low home bias (or high trade openness), the threshold is never reached, and there is always a unique symmetric equilibrium.
} 
In other words, country $i$ 's relative payoffs of pegging to the dollar instead of the euro, $U_{i}(\$)-U_{i}(€)$, depend on how much better it is for $i$ to peg to the dollar when $j$ also pegs to the dollar, i.e. $U_{i}(\$, \$)-U_{i}(€, \$)$, and how much better (or worse) it is for $i$ to peg to the dollar when $j$ pegs to the euro, i.e., $U_{i}(\$, €)-U_{i}(€, €)$.

Using the fact that $p_{j}(€)=1-p_{j}(\$)$, we can rewrite the above expression as

$$
U_{i}(\$)-U_{i}(€)=\alpha+\beta p_{j}(\$)+\mu\left(\varepsilon_{i}(\$)-\varepsilon_{i}(€)\right)
$$

where

$$
\begin{aligned}
& \beta=\left[U_{i}(\$, \$)-U_{i}(\$, €)\right]+\left[U_{i}(€, €)-U_{i}(€, \$)\right] ; \\
& \alpha=\left[U_{i}(\$, €)-U_{i}(€, €)\right] .
\end{aligned}
$$

This gives

$$
p_{i}(\$)=\frac{1}{1+e^{-\frac{1}{\mu}\left[\alpha+\beta p_{j}(\$)\right]}},
$$

where we can see that the simple payoff matrix above was a special case, with $\alpha=-1$ and $\beta=2$.The parameter $\beta$ can be interpreted as a measure of the strength of network externalities. When $\beta>0$, network externalities are positive, since the probability that a given country adopts a dollar anchor increases with the probability that its "random trade partner" is anchored to the dollar, which equals the share of $i$ 's trade that takes place with dollar-anchoring countries. When $\beta<0$, network externalities are negative, since the probability of pegging to the dollar decreases with the share of trade with dollar-anchoring countries. When $\beta=0$, network externalities are absent, since the slope of the best response function is zero. In this case, we have

$$
U_{i}(\$, \$)-U_{i}(€, \$)=U_{i}(\$, €)-U_{i}(€, €),
$$

which means that the relative payoffs of pegging to the dollar are the same regardless of the anchor choices by trade partners.

\section{Anchor-specific payoffs (Figure 7)}

In Figure 7, we illustrate how our model is affected by the existence of anchor-specific payoffs. The dark bold line going through the point $(0.5,0.5)$ is an example of a best response function for the model without anchor-specific payoffs, which as we have shown exhibits multiple equilibria if idiosyncratic preferences are not too strong. Now suppose that the dollar is considered a more stable currency than the euro, in terms of the level and variability of U.S. inflation. This would not affect $\beta$, but it would affect $\alpha$, since $\alpha=U_{i}(\$, €)-U_{i}(€, €)$ measures the relative payoffs of pegging to the dollar given a particular trade partner anchor choice. Intuitively, when dollar-specific payoffs exist, the probability of pegging to the dollar increases independently of how popular the dollar is among trade partners (i.e., independently of the size of network externalities). This means that the best response function shifts upwards. Similarly, the existence of euro-specific payoffs implies that the best response function shifts downwards.

As Figure 7 shows, a sufficiently large upward shift of the best response function (which occurs when dollar-specific payoffs exceed euro-specific payoffs) implies that the multiple equilibria disappear and that there is only one unique equilibrium left, in which the majority of countries peg to the dollar. Similarly, a sufficiently large downward shift of the best response function (which occurs when euro-specific payoffs dominate) implies that the majority of countries will end up pegging to the euro. 


\section{Multiple equilibria, coordination failure and path dependence}

The existence of network externalities in anchor currency choice implies the possibility of market failure (or coordination failure). To see this, consider the example in Tables 3a and 3b.

Table 3a. Initial payoff matrix

\begin{tabular}{|c|c|c|}
\hline & $\boldsymbol{A}_{j}=\mathbf{\$}$ & $\boldsymbol{A}_{j}=\mathbf{€}$ \\
\hline $\boldsymbol{A}_{i}=\mathbf{\$}$ & 3,1 & $2,0.5$ \\
\hline $\boldsymbol{A}_{i}=\boldsymbol{€}$ & 0,0 & $1,1.5$ \\
\hline
\end{tabular}

Table 3b. Subsequent payoff matrix

\begin{tabular}{|c|c|c|}
\hline & $\boldsymbol{A}_{j}=\$$ & $\boldsymbol{A}_{j}=\mathbf{€}$ \\
\hline $\boldsymbol{A}_{i}=\$$ & 1,1 & $0,0.5$ \\
\hline $\boldsymbol{A}_{i}=\boldsymbol{€}$ & $0.5,0$ & $1.5,1.5$ \\
\hline
\end{tabular}

The payoff matrix in Table 3a assumes that choosing a dollar anchor has payoffs for country $i$ that are independent of the trade partner's anchor choice (e.g., because country $i$ 's main exports are sold to the United States or its liabilities are dollarized), and these payoffs are large enough so that country $i$ will always prefer to peg to the dollar. That is, pegging to the dollar is a dominant strategy for country $i$. Country $j$, instead, enjoys some euro-specific payoffs, but these payoffs are not large enough to offset dollar bloc network externalities. Then, according to the payoffs in Table $3 \mathrm{a}$, the unique Nash equilibrium is for both countries to peg to the dollar, even though country $j$ would be better off if both pegged to the euro.

Now suppose, as expressed in Table $3 \mathrm{~b}$, that the dollar-specific payoffs to country $i$ disappear (e.g., because country $i$ is at war with the United States), while both countries now enjoy some eurospecific payoffs. Then there are two Nash equilibria again, and both countries would be better off to switch to the Nash equilibrium in which both are pegging to the euro. However, in the absence of any communication or coordination between the two countries, country $i$ will continue to peg to the dollar because country $j$ does so, and $j$ continues to do so because $i$ does so. Thus, the choice of the dollar is path dependent.

In this example, the path dependence actually implies a coordination failure in the sense that both countries would be better off if they simultaneously decided to switch to pegging to each other's currency or perhaps decided to create a local monetary arrangement. ${ }^{16}$ While re-coordinating in a two-country world would be relatively simple, the complexity of negotiating another arrangement when more countries are involved could delay or even deter the emergence of the socially optimal arrangement - the time it took to establish EMU is a case in point.

\section{EMPIRICAL METHODOLOGY}

As the analysis above has shown, the existence of transaction costs to trade arising from exchange rate volatility implies the existence of network externalities: i.e., the payoffs of choosing a given anchor currency increase with the number of countries using the same anchor currency. In

\footnotetext{
${ }^{16}$ Ogawa and Ito (2000) present a model that displays such possibilities. Yehoue (2004) studies currency union formation in a dynamic setup and demonstrates trade flows to be an important determinant.
} 
particular, we found that the relative payoffs for country $i$ of adopting a given anchor $A$, relative to a different anchor $A^{\prime}$, increase with the fraction $p_{j}(A)$ of other countries that adopt the dollar:

$$
U_{i}(A)-U_{i}\left(A^{\prime}\right)=\alpha+\beta p_{j}(A)+\mu\left(\varepsilon_{i}(A)-\varepsilon_{i}\left(A^{\prime}\right)\right)
$$

where $\beta$ measures the strength of network externalities, and $\varepsilon_{i}(A)$ indicates the country-specific preference for anchor $A$. Empirically, we measure $p_{j}(A)$ by the total amount of trade with the all countries that use this anchor currency (including the country that issues this anchor currency, if one exists) relative to GDP. ${ }^{17}$ When we divide through by GDP, we can still interpret this roughly as the empirical probability that a transaction made by a local resident will take place with the anchor country or a country pegged to the anchor. Ideally we would like to take the total value of international transactions with the relevant countries as the numerator and have the denominator be equal to the sum of the value of all domestic transactions and the value of all international transactions. Absent all of this information, we feel this is a good proxy.

In our empirical approach, we use a multinomial logit setup to control for other determinants of anchor choice besides trade flows. In particular, we control for the choice to peg in the first place (to any anchor), by simultaneously modeling the choice of exchange rate regime and the choice of anchor. Using country-years as the observational unit, the choice made by a given country in a given year is thus whether to adopt a peg to any of several anchors, to adopt a float, or to adopt a "freely falling" regime. ${ }^{18}$

The payoffs to country $i$ in year $t$ from a peg to any particular anchor currency $A$ can thus be written as:

$$
U_{i t}^{A}=\beta_{j}^{A} \sum_{j} t_{i j t} I\left(A_{j t}=A\right)+\sum_{k} \beta_{k}^{A} x_{i t k}+\sum_{l} \beta_{l}^{P e g} y_{i t l}+\sum_{m} \beta_{m}^{A} z_{t m}+e_{i t}^{A}
$$

where $\beta_{j}^{A}$ measures the strength of network externalities, $\sum_{j=1}^{J} t_{i j} I\left(A_{j}=A\right) \equiv p_{j}(A)$ is the weighted

average of trade partners $j$ that peg to anchor $A$, and the residual $e_{i t}^{A}$ measures unobserved country characteristics.

To estimate country-specific preferences (denoted by $\varepsilon_{i}(A)$ in the model), the vector $x_{i t k}$ contains the $k$ observed characteristics of country $i$ that affect the anchor choice $A$ (e.g., the currency denomination of debt, the symmetry of shocks, and a country's past experience with an anchor). The vector $y_{i t l}$ contains the $l$ country-specific characteristics that affect the choice whether to peg, float or fall (e.g., openness, reserve cover, and financial development). The vector $z_{t m}$ contains the $m$ anchorspecific characteristics that affect anchor choice (e.g., the level and variability of inflation in the

\footnotetext{
${ }^{17}$ In our robustness checks, we allowed for the problem of endogeneity between trade levels and exchange rate regime choice (or equivalently, exchange rate volatility) by using simply the number of countries in a region that are pegged to a particular anchor, instead of the trade-weighted average.

${ }^{18}$ Eichengreen and Bayoumi (1999) look at de facto pegs in a slightly different way. They regress bilateral exchange rate volatility on the level of bilateral trade, the synchronicity of output shocks, and several other variables to control for the choice of whether to peg or not. This approach, unlike ours, is unable to explain why two small countries that both peg to the dollar, and that have little bilateral trade, but lots of trade with the United States, would have such low bilateral exchange rate volatility. These countries would be extreme outliers to the extent that trade flows matter in their final specification. In addition, Eichengreen and Bayoumi's (1999) approach looks at the choice as a bilateral option with a simple linear relationship, while we prefer to think of the choice between blocs as a possibly highly nonlinear relationship. Finally, our sample is much broader than theirs.
} 
anchor-currency issuing country). The elements of $x_{i t k}, y_{i t l}$, and $z_{i t m}$ are described in detail in the next section. Note that the coefficients on variables that affect anchor choice are allowed to vary over regimes and anchor choices, but that the coefficients on $y$, the variables that determine whether to peg or float, are constrained to be the same over all anchor choices because all anchors are pegs.

We normalize the payoff from floating to 0 and assume that the payoff from freely falling is given by

$$
U_{i t}^{\text {Fall }}=\sum_{k} \beta_{k}^{\text {Fall }} y_{i t k}+e_{i t}^{\text {Fall }}
$$

This equation shows how we constrain the coefficients for a number of variables to equal zero, based on a priori theoretical reasoning and the limits of the data. Here, the vector of country characteristics that enters the "choice" to fall is the same as that for the choice to peg, but the coefficients are allowed to differ. This implicitly assumes that these factors do not differentially affect whether a country pegs to the dollar, the franc or the mark. ${ }^{19}$ We also constrain the parameters associated with anchor choice to be zero for the freely falling category. Finally, we impose a number of constraints on the coefficients on other variables. Essentially we constrain the coefficients on the variables we believe determine regime choice to be the same across all peg choices. An appendix in the working paper version describes the constraints and the reason for imposing them.

We assume that the country's idiosyncratic terms are independent and identically distributed Weibull, so as to implement a standard multinomial logit model with maximum likelihood. The categories in the multinomial logit likelihood function that we use are: peg to the US dollar, peg to the French franc, peg to the German mark, float, or freely falling. ${ }^{20}$ Thus, we analyze whether countries, if they pegged, preferred to peg to the dollar, the mark, or the franc. In our baseline specification of Table 4, we study the limited period 1990-1998 because our debt data begin then, while other series do not stretch into the $21^{\text {st }}$ century. Table 5 and other sensitivity checks extend the sample backward and forward without changing the qualitative results.

An alternative specification to the basic multinomial logit model that we considered (but do not report) is the nested logit model. In such a model, a country would be assumed to first choose whether to peg, float or freely fall, and only then (after having decided to peg) to choose amongst a set of anchor currencies. The benefit of using nested logit is that, over certain groups of choices, one can relax the independence of irrelevant alternatives (IIA) assumption that is inherent in the multinomial logit model. In intuitive terms, the multinomial logit makes it such that if an equally attractive anchor to the dollar, say, appears on the scene for some reason that the sample frequency of all types of pegs relative to floats and free falls would increase. This is clearly not desirable and quite unrealistic. Luckily, the set of anchors is relatively fixed over the sample period 1980-1998 so the thought experiment is not very applicable. Moreover, our arguments suggest that any two anchors would rarely be perfect substitutes (unlike the canonical red and blue busses) conditional on our list of control variables. To be even more concrete, it is unlikely that countries would want to peg to the unpopular floating currency of a small nation precisely because trade flows associated with such a

\footnotetext{
${ }^{19}$ Testing this directly with the full set of variables is difficult because in the multinomial logit setup there are quite a large number of coefficients to estimate relative to the observations we have. This justification is purely based on theoretical considerations. Nevertheless, it is probably misleading to say a variable like the level of reserves would have exactly the same estimated coefficient for any two choices. We are aware that doing so may bias these coefficients. But since we are mainly interested in other variables and in the qualitative marginal effects rather than the exact magnitudes of these marginal effects we have chosen to specify the model this way. ${ }^{20}$ While our data set included other anchors, the complete set of control variables only allowed us to use these three anchors in our tests. For example, it was infeasible, given our control variables, to include anchors like the Yen, the Rand or the Australian dollar, which had very few actual adherents. We were able to include the British pound in earlier years by eliminating certain control variables, but decided against presenting this in our headline results because the costs (having to eliminate important regressors) exceeded the payoffs (one extra anchor, but similar results on network externalities). Still, our qualitative results regarding network externalities below are supported by including sterling.
} 
currency, the amount of debt denominated in such a currency and the symmetry of output shocks with that country are all likely to be small. Aside from the list of anchors we included, there are very few viable choices for anchors conditional on the observed characteristics of countries.

Nevertheless, we tried several nested logit specifications. But we did not find any evidence of unobservable common traits amongst our anchor choices which would show up if the multinomial framework was invalid. In other words, we did not find any evidence that the IIA assumption is violated once we condition on trade links and other factors. We also tried to see if there was any unobservable correlation between the various included anchors by testing limited multinomial models, but we did not find much evidence for this either. ${ }^{21} \mathrm{~A}$ final reason why we did not see much benefit from using nested logit is that, given the way we constrain our coefficients in anchor choice, our multinomial model actually does allow us to conceptualize the observed choices in a way similar to a nested logit. That is, by holding constant the factors that affect regime choice (pegging versus floating), we can estimate the determinants of anchor currency choice conditional on pegging.

\section{EMPIRICAL DETERMINANTS OF ANCHOR AND REgIME CHOICE}

This section describes our control variables, which we split into three groups: (A) anchorspecific determinants of anchor currency choice; (B) country-specific determinants of anchor currency choice; and (C) country-specific determinants of regime choice. The key variables for group A are the historical (10-year average) level of inflation in the country issuing the anchor currency, and the standard deviation of the annual average inflation rate in the anchor-issuing country for the previous 10 years. Group B variables include the symmetry of output shocks, the amount of trade with a particular bloc, the currency denomination of debt, the level of financial dollarization, and shared legal colonial or political histories, as embodied in regional indicators and of course trade patterns. Finally, group $\mathrm{C}$ variables include openness to international trade and capital flows, the nature of shocks, and the need for credibility.

\section{A. Anchor-Specific Determinants of Anchor Currency Choice}

In order to capture the notion that "stable" currencies may be more likely to be chosen as anchors, we attempted to control for the average and the standard deviation of inflation in the anchor country over the previous ten years. Goodhart (1989) argues that a key currency should be stable in value, so that its price relative to other currencies provides sufficient information to make it generally accessible to market participants, making it unnecessary for them to undertake costly investigation. Kouri and Macedo (1978) also emphasize the importance of comparative price stability for the choice of an international currency. They show that the optimal currency composition of a portfolio depends on the risk aversion of the investor and the variance and covariance of currencies' purchasing power. They find that "the safest currency for all investors, regardless of their country, is the currency of the country with the least unpredictable inflation. In the absence of capital controls and restrictions on the use of foreign currencies, we would expect the safe currency to gain increasingly widespread use as the unit of denomination of financial instruments."

However, we did not find any statistical relationship between either of these two variables and anchor choice. The main reason for this result is most likely that the anchors in our dataset did not differ enough, in terms of their inflation properties, to be discernible in the estimation. While it is hard to believe that a viable anchor would have a bad inflationary track record, testing this in the context of our econometric model is difficult because we must focus on choices that are available and

\footnotetext{
${ }^{21}$ For example, we left out the franc anchor option and the variables associated with this anchor choice, and reestimated the multinomial logit including only the dollar, mark, fall and float options. We then compared the estimated coefficients on the choices affecting a dollar anchor in this specification to the full specification. While Hausman-type tests did not meet the asymptotic criteria, the coefficient magnitudes did not seem to change too much.
} 
have actually been taken. For example, it would be impossible to test whether inflation in Mexico has been a factor limiting the choice of peso anchors, since there are no peso anchors in our dataset. Similarly, it would be difficult to argue that high inflation in Mexico raised the probability of pegging to the dollar for sample countries, since this may as well have been due to high inflation in Iceland or any other country that experienced high inflation at that time..$^{22}$

\section{B. Country-Specific Determinants of Anchor Currency Choice}

There are almost certainly costs to linking up to a particular currency when there are large asymmetries in output shocks. Differences in output movements would naturally make policy autonomy more valuable. The larger the asymmetries in the shocks between one country and a particular bloc, the more costly it would be for these countries to have identical monetary policies. We operationalize these asymmetries by using the standard deviation of the difference of log growth rates of real output over the previous fifteen years. The difference in growth rates is taken between country $i$ and the country which supplies the anchor currency.

OCA theory was born in an era when international capital movements were relatively limited. But today, with increased capital account liberalization and development prospects, international capital flows denominated in dollars and euros are very important for a large group of countries. It is possible that countries attempt to lock the exchange rate in order to minimize transaction costs on capital flows. As a proxy for these payoffs, we use data made available by the Bank for International Settlements on the level of total outstanding claims (loans, securities and other liabilities) to all sectors issued abroad and denominated in the anchor currencies. We convert all values into US dollars. ${ }^{23}$ As with trade, we normalize these liabilities by nominal GDP.

\section{Country-Specific Determinants of Regime Choice}

We follow standard theoretical arguments and some of the extant empirical literature in choosing a fairly large set of determinants for the peg/float choice. While the list is surely not fully complete, and alternative sets could be used, this proves a useful starting point for comparison to earlier approaches and can easily be amended. To a certain degree, efficiency gains arising from parsimony have been traded for possible increases in bias of the coefficients.

We control for the size of international trade relative to GDP. The model above suggests that fewer international transactions as a proportion of all transactions would lead to a lower payoff from pegging an exchange rate to any possible anchor. Also, countries that trade a lot could be exposed to terms of trade shocks and could benefit from flexibility in the nominal exchange rate. Our data come

\footnotetext{
${ }^{22}$ For the same reason, it is difficult to test for other variables that could be anchor-specific determinants of anchor currency choice. For example, several of such variables would emerge from the literature on international currencies. The anchor currencies in our choice set are mostly considered "international currencies" in the sense that they are often used for invoicing, for denominating debt and other liabilities, and make up a significant proportion of foreign reserve holdings. While we do control for trade flows, debt denomination, and the relative importance of dollar invoicing, other potentially important factors for becoming an international currency include variables such as political stability and the financial development of the country issuing this currency. Tavlas and Ozeki 1992 (p. 3) argue that, for a country's currency to become used internationally (for trade to be financed in its currency), this country should possess financial markets that are broad, deep, and substantially free of controls. For example, the dominance of sterling in international trade during the late nineteenth century reflected in part the fact that London was an important financial center. But these variables find the same problems in the data as the control for inflation in the anchor countries.

${ }^{23}$ The data were graciously provided to us by Ugo Panniza. Some indication of the construction of the data and the sources is given at http://www1.oecd.org/dac/debt/. We also exclude some of the countries with the highest debt to GDP values as these appeared to be extreme outliers. Depending on whether this selection process is unrelated to the other regressors or not, this could have consequences for our estimated coefficients.
} 
from the IMF International Financial Statistics database. Openness is measured as total imports and exports divided by PPP adjusted GDP, where the numerator and denominator are in measured in real terms.

The effect of capital account openness is also theoretically ambiguous. On the one hand, countries that borrow abroad may have strong incentives to peg the exchange rate. Because there may not be hedging mechanisms, or possibly because countries want to economize on such insurance contracts, an exchange rate peg can ensure that the volatility of returns is not affected (too much) by exchange rate slippage. On the other hand, large capital flows and a pegged exchange rate are not compatible with an independent monetary policy according to the Trilemma argument (see, for example, Obstfeld and Taylor, 1998). Hence countries exposed to large capital flows may forgo a peg and opt for a float in order to avoid loss of an independent monetary policy. We measure capital account openness as in Juhn and Mauro (2002). This is the total of inflows and outflows of assets and liabilities divided by nominal GDP. The data come from the IMF's International Financial Statistics.

Countries holding large amounts of reserves can more easily maintain the credibility of a peg and so may be more likely, all else equal, to choose a pegged exchange rate. In a simple first generation currency crisis model (e.g., Krugman, 1979), a government running an excessively expansionary policy runs out of reserves over time. This precipitates the speculative action that dooms a peg. The likelihood of seeing a peg in any given year, then, is a function of international reserves. We normalize reserves by M2 and in certain specifications by the amount of annual imports. All data come from the IFS.

Financially developed countries may be more successful at adopting and maintaining pegs. Prudent regulation of the banking system and financial markets may allow for a deep financial system to emerge and more sustainable outcomes, rather than booms, busts, the eventual currency crisis due to oversight, recklessness and cronyism. But again, there is the possibility of ambiguity here. As argued in Levy-Yeyati, Sturzenegger and Reggio (2002), a more developed financial system could be synonymous with greater exposure to international capital flows. For countries wishing to maintain autonomous monetary policy, this would mitigate against the choice of a peg. To measure financial development, we use the proportion of quasi-money (M2) in the total monetary stock. As another control for financial development, we also control for per capita GDP, by including separately the log of the population and the log of real PPP-adjusted GDP. All monetary data come from the International Financial Statistics. GDP and population data come from the World Bank's World Development Indicators.

Countries may be able to import monetary policy credibility by pegging the exchange rate to the currency of a country with a reputable monetary authority or by foregoing control over monetary policy. The recent past has seen the implementation of new currency boards in Argentina, Bosnia and Herzegovina, Bulgaria, Djibouti, Estonia, and Lithuania. Other examples are currency unions of small countries, such as the Eastern Caribbean Currency Union and the CFA franc zone in Africa.

Moreover, various types of more flexible pegs are often regarded as mechanisms to focus inflationary expectations and hence to control actual inflation. We measure the potential need to import policy credibility with an indicator variable that takes the value one when a country experienced a bout of high inflation between the current year and 1950. We define a country to have had "high inflation" if the country had entered the freely falling category, as defined in the Reinhart and Rogoff data.

According to standard open-economy macroeconomic theory embodied in the MundellFleming-Dornbusch type of models, countries with large real shocks relative to nominal shocks might prefer to use the exchange rate as a shock absorber, and therefore might be less likely to peg. Conversely, in countries where nominal shocks are more important, a peg or quasi-peg can eliminate or reduce these shocks by forcing the money supply to adjust in the appropriate direction. We measure real shocks with the volatility of the previous five-year's investment to GDP ratio. Exposure to nominal shocks is measured by the volatility of the previous five-years' velocity of the money supply. Data on the money supply and real output come from the IFS.

Countries are not likely to actively engage in a decision making process about their regime in each year. But if we were to use a standard multinomial logit model with no control for past outcomes 
on a panel data set we would be implicitly assuming that the choice was taken independently in each and every year regardless of previous experience. ${ }^{24}$ There would also likely be serial correlation in regime choice, making inference problematic. A more realistic assumption then might be that countries come to a point when a decision needs to be made and that decision persists until events change radically — for example, in case of a speculative attack, a major political event or a major economic shock. To capture this idea of persistence, we include the lagged values of anchor choice. ${ }^{25}$

\section{RESUltS}

\section{A. Determinants of Regime Choice: Pegs versus Floats}

The output from maximum likelihood estimates reported are reported in Table 4 and Table 5. Table 4 provides results for a sample ranging between 1990 and 1998 which are the years that detailed data on currency denomination of debt is available. Table 5 leaves out these debt variables and is able to expand the sample back to 1980 .

Results in Table 4 are fairly consistent with the traditional economic interpretation of pegs versus floats. More financially developed countries appear to be more likely to peg than float. Richer countries seem much less likely to peg. Finally, countries with greater volatility of real shocks, as measured by the volatility of domestic investment, are less likely to peg their exchange rates. Trade openness is negatively associated with pegging (or quasi-pegging), although in Table 5 it is positively associated with pegging, buteven here the estimated partial effect is quite small in magnitude. There is strong evidence that nations use U.S. dollar anchors and mark anchors to regain credibility or stabilize inflation. The coefficient and estimated partial effect of this variable for dollar anchors is large and highly significant. The partial effect for mark anchors is much smaller. At the same time, nations with previous high inflations also seem more prone to succumbing to another episode.

The ratio of reserves to total money has a small positive coefficient and is not statistically significant. More exposure to capital flows is negatively related to pegging, suggesting that nations may opt for enhanced domestic monetary policy, rather than exchange rate stability, when making the peg/float choice in the face of the impossible trilemma. This is somewhat consistent with results from Obstfeld, Shambaugh and Taylor (2004). Finally, the incidence of nominal shocks as measured by the volatility of the velocity of money, has a negative sign in Table 4, which is opposite from that of the standard theoretical literature.

\footnotetext{
${ }^{24}$ Our dataset combines observations that have transitions into pegs, floats or falls and observations that have continuing pegs, floats and falls. With the exception of a few types of changes, transitions from different regimes are relatively rare. This is one reason to pool all the data and simply use lagged indicator variables to allow for state dependent transition probabilities. Nevertheless, one might want to estimate a full conditional transition model. One might do this under the assumption that different variables or changes and levels of variables affect regime choice in any given year differently. In addition to a pooled multinomial approach, we thus tried to run an unrestricted transition model (see Beck, Epstein, Jackman and O'Halloran 2002). We ran two multinomial logits. One had only observations that stayed in the same regime as the previous year and one had only observations that moved into their current regimes from a different regime. The assumptions about duration dependence and state independence are strong in such a model, but practically speaking the data do not allow for much more. In any case, we find that our baseline model, itself a restricted transition model, is for all intents and purposes the same as running the unrestricted transition model. In other words, most of the identification of our coefficients is coming from between-country differences in variables as they relate to similar long-run regime choices. In Tables 4 and 5, the estimated coefficients relate to long-run coefficients, as they might in a continuous dependent variable standard time-series setting.

${ }^{25}$ In addition, we included in some specifications a set of time indicators which can, under certain assumptions, allow for duration dependence or serial correlation in regime choice (see Maddala, 1987 or Beck, Katz and Tucker, 1997 and Bernhard and Leblang, 1999). We eliminate some of the controls for lagged regimes, since in practice there is no data for such observations. For example, no country moved from a mark anchor to a dollar anchor in our sample. A look at the information contained in the sample transition probability matrix will show other constraints the data impose.
} 
Our results also show that there is very strong persistence in regime choice. The estimated marginal effect on the lagged indicators for each regime suggest that regime choice is strongly explained by the previous year's regime choice. Also, countries that had a pegged exchange rate regime in the previous year appear to be much less likely to float than countries that floated in the previous year. It is notable that, when we predict regime adherence, our predictions are usually a year behind actual regimes at times of transition, suggesting, not unsurprisingly, that our model has trouble predicting exactly when a switch will occur. It thus appears that our main source of identification is the cross sectional variation in the data, rather than the time series variation.

\section{B. Determinants of Anchor Currency Choice}

Tables 4 and 5 demonstrate that trade network externalities appear to matter a lot for anchor currency choice, as in the way our model demonstrates. This is exhibited by the positive signs on our coefficients on within-bloc trade for anchor choice, reported in Table 4. On the one hand, we find that, for each type of anchor choice, the partial derivative of the probability of adopting a particular anchor with respect to the ratio of trade to GDP with a given anchor bloc is positively associated with regime choice. On the other hand, the partial derivatives with respect to trade with other blocs are mostly negatively associated with anchor-specific payoffs. In the next section, we provide some way to gauge how important these trade variables might have been for determining the patterns of regime adherence we have seen in the past.

The estimated coefficients and their marginal effects on the variable associated with synchronicity of shocks give some additional support for an "optimal anchor currency area" theory. For dollar and mark anchors, an increased co-movement of nominal output is associated with an increased propensity to adopt a particular anchor. This can be seen in Table 4 in the columns showing the marginal effects. There are also some interesting cross-terms in this estimation. First, decreased synchronicity with German output increases the chances of a dollar anchor. Second, the coefficient on the franc anchor is opposite to what we would expect and to what we see for the other anchors. The data seem to tell us that the chances of adopting a franc anchor decrease, rather than increase, with the co-movement with the French economy. One reason for this finding could be that the countries that have a franc anchor (which are mainly African countries) are so structurally different from France. Another reason could be that domestic monetary policy is less of an issue because of the difficulties of tailoring a domestic monetary policy in these small open economies.

Table 4 also provides evidence that the denomination of debt matters in an intuitive way. The coefficient on dollar liabilities means that having more dollar liabilities is associated with a higher probability of pegging to the dollar. More anchor-currency specific debt relative to GPD also seems to be associated with an increased propensity to peg to the franc and the mark. The partial derivatives, however, are quite small and suggest a marginal role for these factors in anchor choice.

\section{Other Factors}

We also include controls for various regions as proxies for political and historical affinities and a control for the commodity composition of exports as a proxy for the currency denomination of exports (since commodities are typically priced in dollars). We find that there do seem to be strong regional preferences. For example, we see that Latin America and the Caribbean have a preference for dollar anchors, while the Eastern European states have a preference for mark anchors. This is true even after controlling for trade relations. One interpretation is that older colonial and quasi-colonial or modern political influences are exerting control and serving to focus anchor strategies in various countries. We find little evidence that petroleum exporters, who nearly always denominate their exports in dollars, are more likely to peg to the dollar. However, we do find evidence that primary commodity exporters (excluding oil) are in fact more likely to peg to the dollar.

\section{Model Fit}


To measure how well our model fits the data, we provide tabulations of predictions for the sample in each of our tables. To decide which regime a country is predicted to have, we assigned each country to the regime that had a probability above a fairly unforgiving 0.75 . With this cutoff rule, we find that our baseline model underpredicts nearly each type of anchor in terms of total numbers, and also quite seriously underpredicts free falls. One possible explanation for this is that free falls are generally crisis episodes, and our list of variables are poor predictors of such crises.

In terms of correct predictions, we present the likelihood that those countries predicted to have a certain type of anchor or regime actually had such an anchor or regime. By this measure we achieve very high success rates. In the lower right hand corner of Table 4 we show that we correctly predict anchor choice over 84 percent of the time, with much higher success rates for dollar and mark anchors than for franc anchors. One can also calculate the ratio of the countries correctly predicted to have a certain regime (peg, float, fall) or anchor to the total number of actual anchor adoptions. The highest percentage of correct predictions occurs for mark anchors at 80 percent. The percentages for dollar and franc anchors were 76 and 56 percent, respectively.

\section{Other Specifications and Robustness Checks}

In this section, we report the results of several other modified specifications. We found that our baseline results changed very little in qualitative terms which strengthens our confidence in the results reported in Table 4. We also discuss other factors that we thought might have played a role in regime choice but were not found to be significant in initial specifications. These variables were dropped from reported models to increase the size of the sample or to put less strain on the data in terms of collinearity. Full results of all non-reported specifications are available upon request.

In Table 5, we report the results of a multinomial regression excluding the currency denomination of debt. Excluding debt data doubles the size of the sample, by allowing more countries to enter and it allows us to extend the sample back to 1980 . We found little evidence that leaving out currency denomination of debt changed our other results dramatically in qualitative terms. The network externality coefficients still have the correct signs but their magnitudes are were smaller.

In Table 5, we also allow the coefficient on past experience to vary by anchor currency, yielding different coefficients for each feasible state in year $t$-1. This allows us to see whether, for instance, having had a mark or a dollar anchor in the previous year had a different impact on the propensity to adopt a mark anchor in the current year. ${ }^{26}$ In this specification (Table 5), the best predictors (in terms of statistical significance) of regime choice were (1) having had a similar anchor in the previous year; (2) trade patterns (network externalities); and (3) the currency denomination of debt. In any case, the results do not suggest that the coefficient on a lagged dollar anchor in the choice of a dollar anchor was much different from the coefficient on a lagged mark anchor in the mark choice. Moreover, there are relatively few observations other than this type in the data, which is to say that most dollar anchors are preceded by either dollar anchors or floats in the previous year. Very few or no franc anchors are seen to have been preceded by other anchors in the previous year. As a result of all this, there is only a limited subset of the possible previous year regime coefficients that are estimable.

We carried out other sensitivity checks as well. First, we included time dummies in the baseline specification in Table 4, which can be interpreted as controlling for environmental or global factors affecting regime choice. We found that time dummies were jointly significant, although individually they were not. None of the other variables became insignificant when time dummies were included. Moreover, there was only a marginal improvement in fit, as measured by the increase in the likelihood value.

Second, instead of including the weighted anchor regime choices of trade partners, we simply included the percentage of countries in a region pegging to each anchor currency in a country's

\footnotetext{
${ }^{26}$ It was infeasible to allow for this in the baseline specification reported in Table 4, because the particular combinations of variables generate collinearity and extremely good predictions of certain pegs, thus automatically dropping some variable in the maximization process.
} 
region, as a measure of regional regime popularity. ${ }^{27}$ The benefit of using such a non-weighted measure of other countries' regime choice is that we avoid somewhat the "endogeneity" between trade flows and exchange rate volatility, which arise from the fact that the transaction costs associated with exchange rate volatility may decrease trade (Frankel, 2003). The results were in line with Table 4 and, if anything, the OCA coefficients were even more precisely estimated.

A third robustness check we carried out was to re-classify countries so as to exclude some of the more "flexible" pegged regimes from the pegged category. Here, we included countries in the peg column only if they had a fine code smaller than 8 as in Table A1 in Appendix 1. In other words, we no longer considered pre-announced wide crawling bands, wide de facto crawling bands, and moving bands as "pegs". The results from this exercise were still broadly in line with our baseline. However, while the sign on the volatility of money velocity was found to be positive, as expected, it was not estimated very precisely.

We also estimated a fourth specification, that included the choice to use the pound sterling as an anchor. An important stylized fact in our dataset, described in section II, is that sterling declined a lot in popularity beginning in the 1960s. The story of sterling's decline in popularity as an anchor currency is more complex than what one regression can capture, and there are of course many individual country experiences combined with political factors. Still, the declining stability of monetary policy in Britain and hence the impact on the pound/dollar exchange rate is arguably a key reason why nations might have preferred other anchors to the pound. Another factor was the fear of capital gains losses on sterling balances, forcing a move to diversify assets and hence leading to other anchor choices. Moreover, to the extent that worries were based on exchange rate movements rather than mounting inflationary problems, this might be evidence for a self-reinforcing dynamic arising from the strategic complementarities we outlined above as a partial explanation for why fewer and fewer countries have chosen a sterling peg over the long-run. ${ }^{28}$ When we estimated a specification similar to that in Table 5, but including the pound as an anchor choice, we found evidence that the choice for a pound anchor was positively associated with the volume of trade with the sterling area. However, the estimated partial derivative was very small, suggesting that the strength of this network externality was relatively small.

Finally, we checked robustness by excluding developed countries from our sample. Doing this shows there is little evidence that the factors driving anchor choice are different than with the full sample. However, the choice to peg or not is apparently slightly different since openness in this case has a positive but insignificant coefficient. This difference is possibly due to the fact that many of the smallest national economies have pegs.

\section{Other Factors that Appear Less Relevant or Are Hard to Test}

Similar to the currency denomination of debt, the denomination of foreign currency deposits could be another important determinant of anchor currency choice. A country may to try to "hedge" this exchange rate risk by anchoring the exchange rate. Unfortunately, we lack sufficient high-quality data for a broad sample to include this variable in our study, but we feel that it might be a contributing

\footnotetext{
${ }^{27}$ We define a region as those countries which border a country and those which have geographical centers within 1800 kilometers measured by great circle methods. As a reference point, Argentina and Brazil are 1707 kilometers apart based on our distance measures. These measures come from data in the CIA World Factbook but were used by and defined in Reuven Glick and Andrew Rose (2002).

${ }^{28}$ Reinhart and Rogoff's data reveal the following information about certain transitions from the pound to the dollar. Australia and New Zealand simultaneously adopted a dollar anchor in 1972. The East Caribbean Central Bank States (Antigua and Barbuda, Anguilla, Dominica, Grenada, Montserrat, Saint Kitts and Nevis, SaintLucia, Saint Vincent and the Grenadines) all went to the dollar at once in 1976. Iraq, Kuwait, and Jordan also adopted their dollar anchors almost simultaneously in 1972. Finally, Myanmar (1975), Sri Lanka (1976), Hong Kong (1972), Malaysia (1976), Pakistan (1972), and Singapore (1972) all moved to the dollar at nearly the same time.
} 
factor, as the literature has noted. To the extent that countries that have suffered past hyperinflation are those that tend to have a dollarized banking system, our coefficient on past hyperinflations could be picking up this effect.

Since the exchange rate regime is normally a political decision, it could be the case that political interests and institutions affect the observed outcomes. Indeed, we can imagine an political economy model of anchor currency choice, where interest groups with trade links with a given bloc will exert pressure on politicians to decrease their transaction costs of trade by implementing a peg. The literature has also argued that institutions and interests are important (see Bernhard and Leblang, 1999).

We used a Herfindahl index of political parties in the polity to measure how likely the system is to give rise to a government with homogeneous interests. We also used an ex post measure of government stability which gauges the turnover in veto players during a given period. Finally, the percentage of seats held in the legislative assembly by the government measures the strength of the actual governing party. These political data came from the Database of Political Institutions. ${ }^{29}$

As a matter of fact, none of the political economy variables we included in our estimations show up as statistically significant. This is not to say that political constraints do not matter. More likely, the data we used are limited and imperfect indicators. We feel that more work should go into the theoretical and empirical exploration of how these factors might influence de facto regimes.

There is also a literature on optimal pegs, which we have neglected thus far. For example, Dornbusch and Park (1999) and Kwan (1994) discuss the issues of competition and output stabilization. Of course, such arguments rely on intimate knowledge of the level of pass-through, the invoicing practices, the direction of trade and the actual level of competition at the aggregate level. Such considerations are interesting but seem daunting in terms of finding appropriate controls and even more difficult for policy makers to consider. Moreover, such prescriptions seem to us plainly normative rather than positive. Since they have only recently been developed in the theoretical literature, we wonder how much policy makers have digested these ideas.

\section{How STRONG ARE NETWORK EXTERNALITIES?}

In order to get a sense of the strength of network externalities, and therefore the likelihood of coordination failure, we measured how strongly other countries' choices affect the geography and incidence of particular anchor currencies. Our main finding here is that within-bloc trade is crucial. To show this, we ran the following counterfactual for each type of anchor: We first supposed that for each country trade with a given bloc was $X$ percent of actual trade (relative to GDP) with that bloc in each year (where $X$ could take the values 100,50 , and 0 ). Then we simply substituted this new counterfactual trade level for actual trade and then predicted regime choice. ${ }^{30}$ One plausible counterfactual would be one which allows us to gauge what might have happened to the other blocs if we apportioned this "lost" trade to trade with these other blocs.

Our first finding is that, when half of all trade with the dollar bloc dries up, the dollar bloc also shrinks significantly. Figure 8 plots actual dollar anchors, and predicted dollar anchors for trade at the 100 percent (actual), 50 percent and 0 percent levels when the lost trade is apportioned to the mark bloc. The size of the dollar bloc is almost half the size of the actual bloc when trade with that bloc is completely reduced. In Figure 9 we show what happens to the mark bloc. We present results

\footnotetext{
${ }^{29} \mathrm{We}$ are open to including additional political variables. For instance, instead of including regional indicator variables, we could control for the degree of political ties between two countries (as proxied, by available data on voting patterns in the U.N.) as a potential determinant of anchor currency choice. Also, pegging implies that a choice must be made about fighting inflation versus easing unemployment. Frankel (2003) suggests that symmetry in political preferences between the anchor country and the pegging country may make it easier to generate a political consensus about the right way to adjust to such a shock. How to control for such symmetry is an interesting question that we leave for further research.

${ }^{30}$ The highest probability out of the five predicted probabilities determines which type of anchor/regime a country is predicted to have.
} 
where we simply add the equivalent of 0,50 , or 100 percent of all trade (relative to GDP) with countries on a dollar bloc to trade with the mark bloc (again, relative to GDP).

The results also suggest that regime choice is nonlinear in trade flows, in that a relatively small amount of regime change can have large effects on the geography of the international monetary system at certain levels. This is suggested by the finding that the percentage reduction in the number of countries pegging to the dollar is slightly larger when moving from 50 to 0 percent of actual trade than when moving from 100 to 50 percent of actual trade. In the reverse direction, this also indicates that marginal additions to the bloc, when these are defections from another bloc, become increasingly less important for regime choice, suggesting that the initial snowball or diffusion effect eventually levels off as marginal additions are made to the bloc.

Finally, we find suggestive evidence that the transaction cost payoffs per dollar of GDP, as estimated by the model, are larger for the dollar bloc than for the mark bloc. This is suggested by Figure 9, which shows what might have happened if each country experienced a significant fall in trade with the dollar bloc and an associated rise in trade with the mark bloc. With the disappearance of the dollar bloc, the mark bloc gains massively in size but captures slightly fewer adherents than are predicted to be lost in the dollar bloc. ${ }^{31}$ This is consistent with the marginal effects we found earlier. Also, the lack of change in the franc bloc shows that the dollar and mark blocs do not provide strong attractions in terms of transaction costs savings for countries that have pegged to the franc.

\section{CONCLUSION}

Virtually all countries that have chosen to peg their currencies in some way to another currency have converged over the last fifty years to using either the U.S. dollar or the euro as anchors for those pegs. This stylized fact raises a number of important questions: Why have some countries chosen to peg their currency to the U.S. dollar while others have chosen to peg to the euro? Why are other currencies no longer popular as anchors? And more generally, what determines the choice of anchor currency in a pegged (or nearly pegged) exchange rate regime?

In this paper, we studied the determinants of anchor currency choice for pegged exchange rate regimes, as well as the determinants of the choice to peg itself. Using a new dataset on de facto exchange rate regimes and a panel multinomial logit framework, we presented evidence that a key factor explaining the convergence to euro (mark and franc) and dollar anchors is the existence of network externalities. These arise because the payoffs of using a particular anchor increase with the amount of trade with countries that use the same anchor.

Our results seem consistent with an "optimal anchor currency area theory," i.e., the optimal currency area theory applied to anchor currency choice. Importantly, we found that trade relations matter, in the sense that exchange rate regime choices appear to be chosen with reference to trading partners' regimes. We also presented some evidence that the size of each currency bloc matters quite a lot for anchor currency choice. For example, we found that, if trade were to exogenously increase with those countries pegging to the U.S. dollar, it would be individually optimal for these countries to switch to a dollar anchor.

In terms of the determinants of the choice to peg as opposed to float, our results are generally in line with standard economic theory. However, just as in many other empirical studies of regime choice determinants, our results do not seem very robust. This is consistent with Juhn and Mauro's (2002) finding that there are no robust empirical regularities in how countries choose their exchange rate regimes.

Three important lessons emerge about the geography of the international monetary system. First, policy advice or political choices regarding exchange rate regimes could have repercussive effects for regime choice in other countries. For example, if a major trading partner adopts a dollar anchor for a given reason, a number of other trading partners may be expected to follow suit.

\footnotetext{
${ }^{31}$ In the case where all trade with the dollar bloc disappears and all of it is apportioned to the mark bloc, the franc bloc barely changes in size. This figure and the underlying data are available upon request.
} 
Depending on the size of the bloc, this could have very large effects on other countries' regime choices. Second, if a large number of countries are pegging to a certain currency, then, in the absence of a large crisis or another unanticipated extreme event, it may be difficult to break out of this pattern into another perhaps more socially beneficial set of arrangements. Countries can be locked into a suboptimal steady state. Third, if such a sub-optimal steady state is reached, the associated use of the sub-optimally chosen anchor currency in international transactions and as a reserve currency (i.e., the use of the anchor currency as a means of payment and store of value) implies that this anchor currency may become overvalued. This, in turn, may give rise to an unsustainably large current account deficit in the anchor currency issuing country, which some would argue has happened in the United States (see for example Obstfeld and Rogoff 2004 and Eichengreen 2004). When the overvalued anchor currency eventually begins to depreciate, like the U.S. dollar has begun to do, a critical amount of depreciation may eventually allow the anchoring countries to break out of the suboptimal steady state and switch to a different anchor (or float). This, in turn, may give rise to a sudden decrease in the willingness of nonresidents to continue funding ongoing deficits, and potentially to a currency crisis. This would not be the first time in history a currency bloc unraveled in this way. The demise of silver standards in the 1870 s and the loss of sterling as an international currency in this century illustrate that such dynamics are a real possibility. 


\section{APPENDIX I: The NATURAL ClASSIFICATION}

This Appendix, based on Rogoff and others (2004), summarizes the data and algorithm used to construct the natural classification. More details on the algorithm used to classify regimes are provided in Reinhart and Rogoff (2004).

Table A1. Regime Classification Codes and Descriptions.

\begin{tabular}{|l|l|l|}
\hline fine & course & Description \\
\hline 1 & 1 & No separate legal tender \\
\hline 2 & 1 & Pre announced peg or currency board arrangement \\
\hline 3 & 1 & Pre announced horizontal band that is narrower than or equal to $+/-2 \%$ \\
\hline 4 & 1 & De facto peg \\
\hline 5 & 2 & Pre announced crawling peg \\
\hline 6 & 2 & Pre announced crawling band that is narrower than or equal to $+/-2 \%$ \\
\hline 7 & 2 & De factor crawling peg \\
\hline 8 & 2 & De facto crawling band that is narrower than or equal to $+/-2 \%$ \\
\hline 9 & 3 & Pre announced crawling band that is wider than or equal to $+/-2 \%$ \\
\hline 10 & 3 & De facto crawling band that is narrower than or equal to $+/-5 \%$ \\
\hline 11 & 3 & $\begin{array}{l}\text { Moving band that is narrower than or equal to }+/-2 \% \text { (i.e., allows for both } \\
\text { appreciation and depreciation over time) }\end{array}$ \\
\hline 12 & 3 & Managed floating \\
\hline 13 & 4 & Freely floating \\
\hline 14 & 5 & Freely falling \\
\hline 15 & 6 & Dual market in which parallel market data is missing \\
\hline
\end{tabular}

\section{The Data}

The natural classification classifies exchange rate regimes into fifteen fine and six coarse categories as summarized above. The classification is based on monthly data on official and market-determined exchange rates for the period 1946-1998. ${ }^{32}$ The market-determined exchange rate data come from various issues of Pick's Currency Yearbook, Pick's Black Market Yearbooks, and Pick's World Currency Report and the official rate comes from the same sources as well as from the IMF. The quotes are end-of-month exchange rates and are not subject to revisions. For the countries that had one or more monetary reforms, involving changes in the units in which the exchange rate is expressed, the data has been converted as necessary to ensure continuity.

\footnotetext{
${ }^{32}$ In some instances, the data for the market-determined rates are available for a shorter period. Observations where the parallel market was known to be substantial but parallel rate data were not available were marked "unclassified."
} 


\section{REFERENCES}

Alesina, Alberto, and Alexander Wagner, 2003, "Choosing (and Reneging on) Exchange Rate Regimes,” NBER Working Paper 9809.

Bayoumi, Tamim, and Barry Eichengreen, 1997, "Ever Closer to Heaven? An Optimum Currency Area Index for European Countries," European Economic Review Papers and Proceedings Vol. 41, pp. 761-70.

Bayoumi, Tamim, and Barry Eichengreen, 1999, "Is Asia an Optimum Currency Area? Can It Become One? Regional, global and historical perspectives on Asian monetary relations," in: Stefan Collignon, Jean Pisani-Ferry and Yung Chul Park (eds.), Exchange Rate Policies in Emerging Asian Countries (London: Routledge).

Bernhard, William, and David Leblang, 1999, "Democratic Institutions and Exchange-rate Commitments," International Organization Vol. 53, No. 1, pp. 71-97.

Beck, Nathaniel, David Epstein, Simon Jackman and Sharyn O’ Halloran, 2002, “Alternative Models of Dynamics in Binary Time-Series-Cross Section Models: The Example of State Failure", mimeo. Stanford University.

Beck, Nathaniel, Jonathan Katz, and Richard Tucker, 1998, "Taking Time Seriously: Time-SeriesCross-Section Analysis with a Binary Dependent Variable (with N. Beck and R. Tucker), American Journal of Political Science Vol. 42, No. 4, pp. 1260-1288.

Beck, Thorsten, George Clarke, Alberto Groff, Philip Keefer, and Patrick Walsh, 2001, "New Tools in Comparative Political Economy: The Database of Political Institutions," World Bank Economic Review Vol. 15, No. 1, pp. 165-176.

Bubula, Andrea, and İnci Ötker-Robe, 2002, "The Evolution of Exchange Rate Regimes Since 1990: Evidence From De Facto Policies," IMF Working Paper 02/155 (Washington: International Monetary Fund).

Calvo, Guillermo A., and Carmen M. Reinhart, 2002, "Fear of Floating," Quarterly Journal of Economics Vol. CXVII, No. 2, pp. 379-408.

Camdessus, Michel, 1995, "The Dollar, The Yen and European Currencies," Address at the XIV Sesiones de Trabajo de Tesoreria, Caja de Ahorros de Navarra, Pamplona, Spain, November 17, 1995 (Washington: International Monetary Fund)

Cuddington, John T., and Samuel K. Otoo, 1990, "Choice of Exchange Rate Regime: A Multinomial Logit Model,” Working Paper No. 90-18 (Washington: Georgetown University).

Dornbusch, Rudiger and Yung Chul Park, 1999, "Flexibility or Nominal Anchors?" in Exchange Rate Policies in Emerging Asian Countries, edited by Stefan Collignon, Jean Pisani-Ferry and Yung Chul Park eds (London: Routledge).

Dowd, Kevin \& Greenaway, David, 1993, "Currency Competition, Network Externalities and Switching Costs: Towards an Alternative View of Optimum Currency Areas," Economic Journal, Vol. 103, No. 127, pp. 1180-89.

Dreyer, Jacob S., 1978, "Determinants of Exchange Rate Regimes for Currencies of Developing Countries: Some Preliminary Results," World Development, Vol. 6, 437-45. 
Edwards, Sebastian, 1996, "The Determinants of the Choice Between Fixed and Flexible ExchangeRate Regimes,” NBER Working Paper No. 5756 (Cambridge, Massachusetts: National Bureau of Economic Research).

Eichengreen, Barry, and Marc Flandreau, 1998, "The Geography of the Gold Standard," in Currency Convertibility: The Gold Standard and Beyond, edited by J.B de Macedo, Barry Eichengreen, and Jaime Reis (London: Routledge).

Eichengreen, Barry "Global Imbalances and the Lessons of Bretton Woods," NBER Working Paper No. 10497 (Cambridge, Massachusetts: National Bureau of Economic Research).

Fasano, Ugo, and Andrea Schaechter, 2003, "Monetary Union Among Member Countries of the Gulf Cooperation Council," IMF Occasional Paper 223 (Washington: International Monetary Fund).

Flandreau, Marc, 1996, "The French Crime of 1873: An Essay in the Emergence of the International Gold Standard, 1870-1880," Journal of Economic History Vol. 56, No. 4, pp. 862-897.

Frankel, Jeffrey A., 2003, "Experience of and Lessons from Exchange Rate Regimes in Emerging Economies," NBER Working Paper No. 10032 (Cambridge, Massachusetts: National Bureau of Economic Research).

Frieden, Jeffry, Piero Ghezzi, and Ernesto Stein, 2000, "Politics and Exchange Rates: A CrossCountry Approach to Latin America," Research Network Working Paper R-421 (Washington: Inter-American Development Bank).

Ghosh, Atish, Anne-Marie Gulde, Jonathan Ostry, and Holger Wolf, 1997, "Does the Nominal Exchange Rate Regime Matter?," NBER Working Paper No. 5874 (Cambridge, Massachusetts: National Bureau of Economic Research).

Glick, Reuven, and Andrew K. Rose, 2002, "Does a Currency Union Affect Trade? The Time-Series Evidence," European Economic Review, Vol. 46, No. 6, 1125-1151.

Goodhart (1989), C “The Conduct of Monetary Policy,” Economic Journal, Vol. 99, No. 396 (June), pp. 293-346.

Hausmann, Ricardo, Ugo Panizza, and Ernesto Stein, 2001, "Why Do Countries Float the Way They Float?," Journal of Development Economics Vol. 66, pp. 387-414.

Heller, H. Robert, 1978, "Determinants of Exchange Rate Practices," Journal of Money, Credit and Banking, Vol. 10, 308-21.

Holden, Merle, Paul Holden, and Esther Suss, 1979, "The Determinants of Exchange Rate Flexibility: An Empirical Investigation," Review of Economics and Statistics, Vol. 61, No. 3 (August), 327-33.

International Monetary Fund, 1999, "Exchange Arrangements and Currency Convertibility: Developments and Issues," World Economic and Financial Surveys (Washington: International Monetary Fund).

Iwami, Toru, 1994, “The Internationalization of Yen and Key Currency Questions,” IMF Working Paper No. 94/41 (Washington: International Monetary Fund). 
Juhn, Grace, and Paolo Mauro, 2002 "Long-Run Determinants of Exchange Rate Regimes: A Simple Sensitivity Analysis," IMF Working Paper No. 02/104 (Washington: International Monetary Fund).

Klein, Michael W. and Jay C. Shambaugh (2004) "Fixed Exchange Rates and Trade" National Bureau of Economic Research working paper number 10696.

Kiyotaki, Nobuhiro, and Randall Wright, 1989, "On Money as a Medium of Exchange," Journal of Political Economy Vol. 97, No. 4 (August), pp. 927-54.

Kouri and Macedo, 1978, "Exchange Rates and the International Adjustment Process," Brookings Papers on Economic Activity, Vol. [1PD], pp. 111-50.

Krugman, Paul, 1979, “A model of balance of payments crises," Journal of Money, Credit, and Banking Vol. 11, pp. 311-325.

Kwan, C.H, 1994, Economic Interdependence in the Asia-Pacific Region: Towards a Yen Bloc. New York: Routledge.

Levy-Yeyati, Eduardo, and Federico Sturzenegger, 2003, “A De Facto Classification of Exchange Rate Regimes: A Methodological Note," American Economic Review, Vol. 93, No. 4.

Levy-Yeyati, Eduardo, Federico Sturzenegger, and Eliana Reggio (2003) "On the Endogeneity of Exchange Rate Regimes” (mimeo), Universidad Torcuato di Tella.

La Porta, R., F. Lopez-de-Silanes, A. Shleifer, and R.W. Vishny, 1998, "Law and Finance," Journal of Political Economy Vol. 106, pp. 1113-55.

Maddala, G. S., 1987, "Limited Dependent Variable Models Using Panel Data." The Journal of Human Resources Vol. 22, No. 3, pp. 305-38.

Masson, Paul, 2001, “Exchange Rate Regime Transitions," Journal of Development Economics, 64(2), pp. 571-886.

Masson, Paul, and Catherine Pattillo, 2001, "Monetary Union in West Africa (ECOWAS). Is It Desirable and How Could It Be Achieved?", IMF Occasional Paper 204 (Washington: International Monetary Fund).

Meissner, Christopher M., forthcoming, "A New World Order: Explaining the International Diffusion of the Gold Standard, 1870-1913," Journal of International Economics

Obstfeld, Maurice and Kenneth Rogoff "The Unsustainable US Current Account Position Revealed" NBER working paper 10869.

Obstfeld, Maurice, and Alan M. Taylor, 1998, "The Great Depression as a Watershed: International Capital Mobility in the Long Run." in The Defining Moment: The Great Depression and the American Economy in the Twentieth Century, edited by M. D. Bordo, C. D. Goldin and E. N. White (Chicago: University of Chicago Press).

Obstfeld, Maurice, Jay C. Shambaugh and Alan M. Taylor (2004) "The Trilemma in History: Tradeoffs among Exchange Rates, Monetary Policies, and Capital Mobility" NBER working paper no. 10396. 
Ogawa, Eiji, and Takatoshi Ito, 2000, "On the Desirability of a Regional Currency Basket," NBER Working Paper No. 8002, November (Cambridge, Massachusetts: National Bureau of Economic Research).

Oomes, Nienke, 2003a, "Network Externalities and Dollarization Hysteresis: The Case of Russia," IMF Working Paper No. 03/96 (Washington: International Monetary Fund).

Oomes, Nienke, 2003b, "Local Trade Networks and Spatially Persistent Unemployment," Journal of Economic Dynamics and Control Vol. 27, pp. 2115-2149.

Poirson, Hélène, 2001, “How Do Countries Choose Their Exchange Rate Regime?,” IMF Working Paper No. 01/46 (Washington: International Monetary Fund).

Reynolds, T., and A. Flores , 1989, Foreign Law: Current Sources of Basic Legislation in Jurisdictions of the World (Littleton, Colorado: Rothman and Co.).

Reinhart, Carmen, and Kenneth Rogoff, 2004, "The Modern History of Exchange Rate Arrangements: A Reinterpretation," Quarterly Journal of Economics Vol. CXIX, No. 1, pp. $1-48$

Rizzo, Jean-Marc, 1998, "The Economic Determinants of the Choice of an Exchange Rate Regime: A Probit Analysis," Economics Letters Vol. 59, No. 3, pp. 283-87.

Rogoff, Kenneth, Aasim Husain, Ashoka Mody, Robin Brooks, and Nienke Oomes, 2004, "Evolution and Performance of Exchange Rate Regimes," IMF Occasional Paper No 229. An earlier version of this paper was published as IMF Working Paper No. 03/243 (Washington: International Monetary Fund).

Savvides, Andreas, 1990, "Real Exchange Rate Variability and the Choice of Exchange Rate Regime by Developing Countries," Journal of International Money and Finance, Vol. 9, pp. 440-54.

Tavlas, George S., and Yuzuri Ozeki, 1992, "The Internationalization of Currencies: An Appraisal of the Japanese Yen," IMF Occasional Paper No. 90 (Washington: International Monetary Fund).

Yehoue, Etienne B., 2004, "Currency Bloc Formation as a Dynamic Process Based on Trade Network Externalities,” IMF Working Paper No. 04/222 (Washington: International Monetary Fund).

Yehoue, Etienne B., 2005, "On the Pattern of Currency Blocs in Africa," IMF Working Paper No. 05/45 (Washington: International Monetary Fund). 
$-29-$

Figure 1. All Countries: Anchor Currency Choices, 1940-2001 (number of countries)

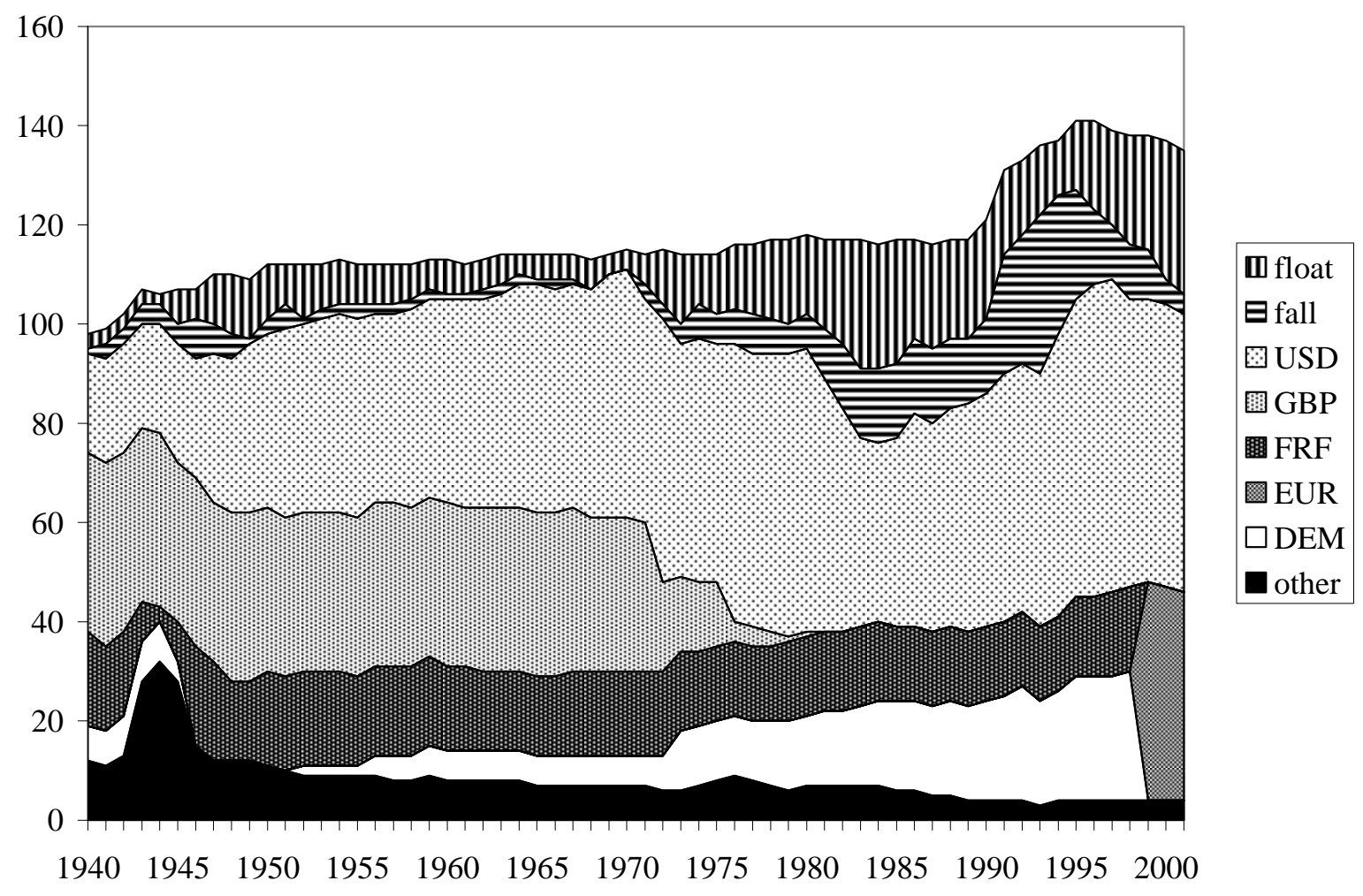

Figure 2. Developed Countries: Anchor Currency Choices, 1940-2001 (number of countries)

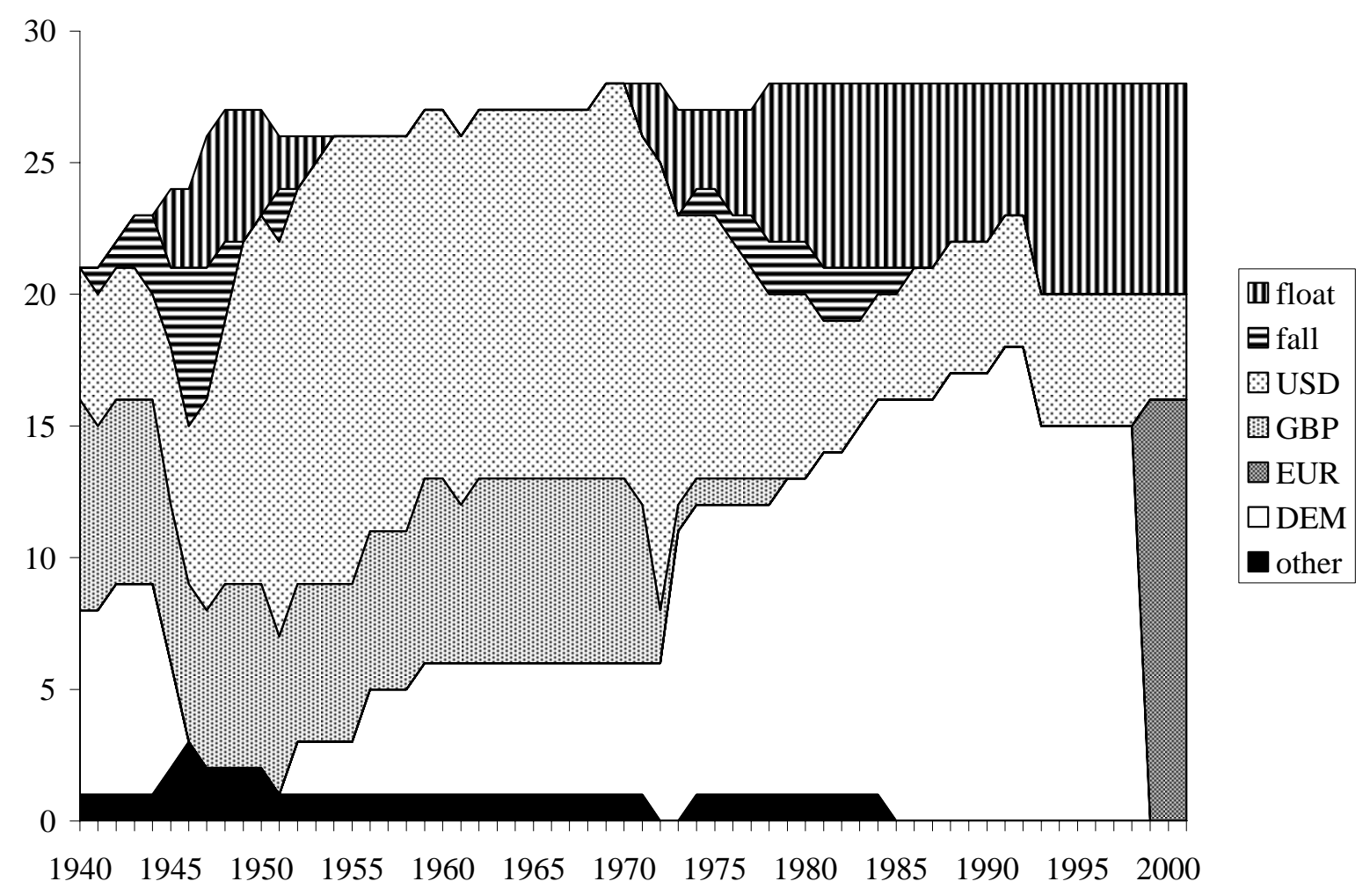


- 30 -

Figure 3. Developing Countries: Anchor Currency Choices, 1940-2001 (number of countries)

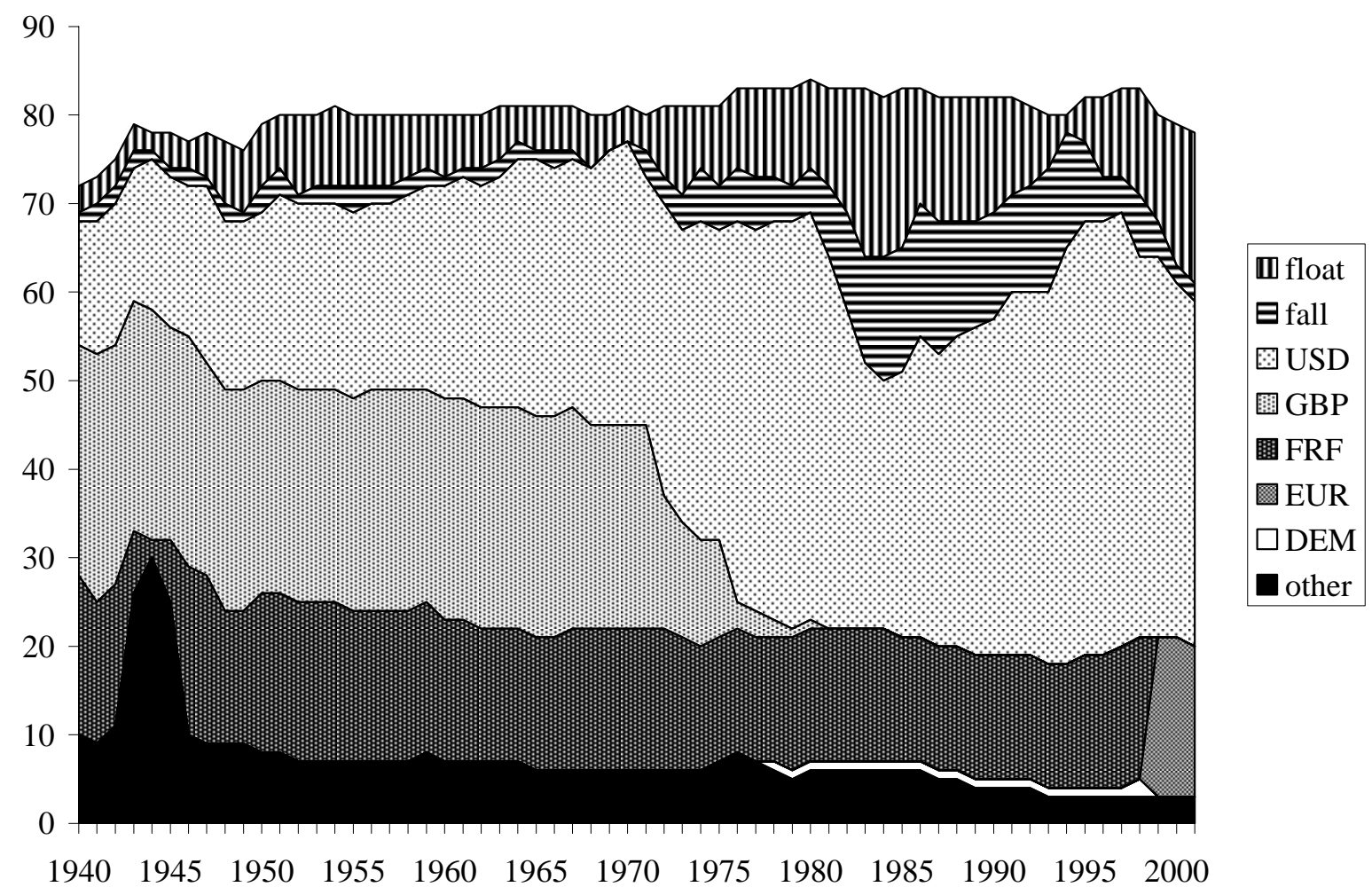

Figure 4. Transition Countries: Anchor Currency Choices, 1940-2001 (number of countries)

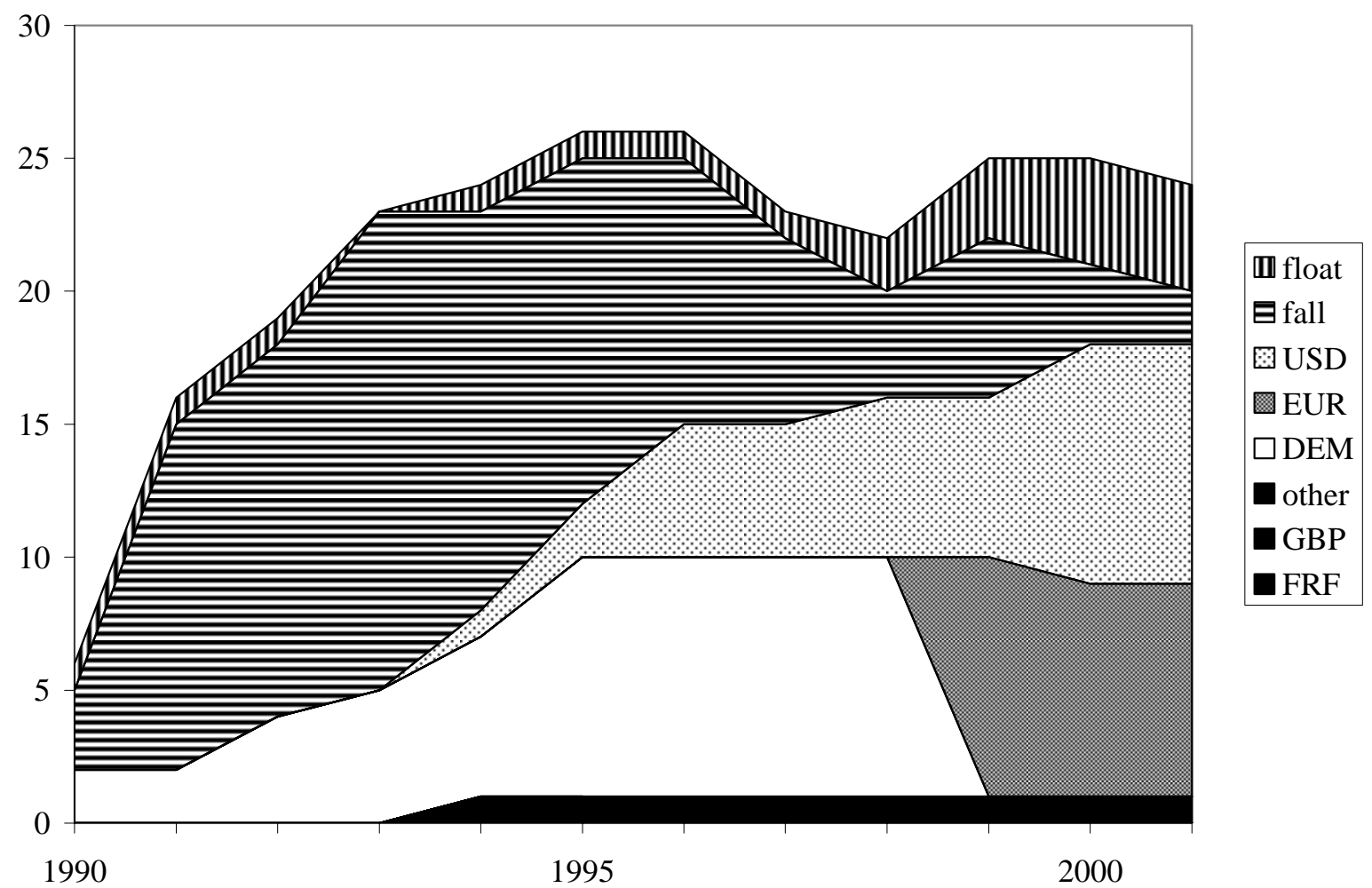


$-31-$

Figure 5. Equilibria of the Deterministic Anchor Choice Model

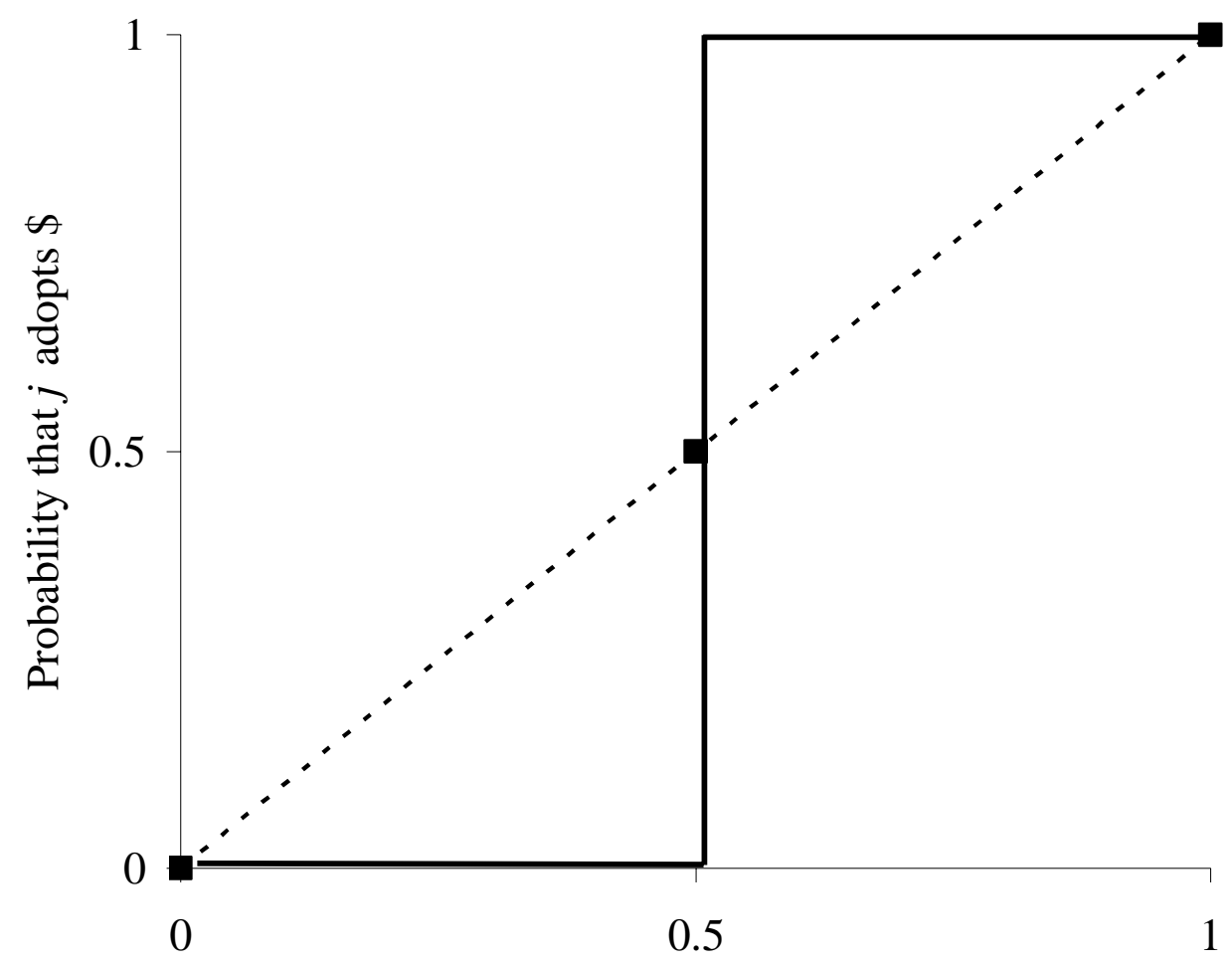

Probability that $i$ adopts $\$$

Figure 6. Equilibria of the Stochastic Anchor Choice Model

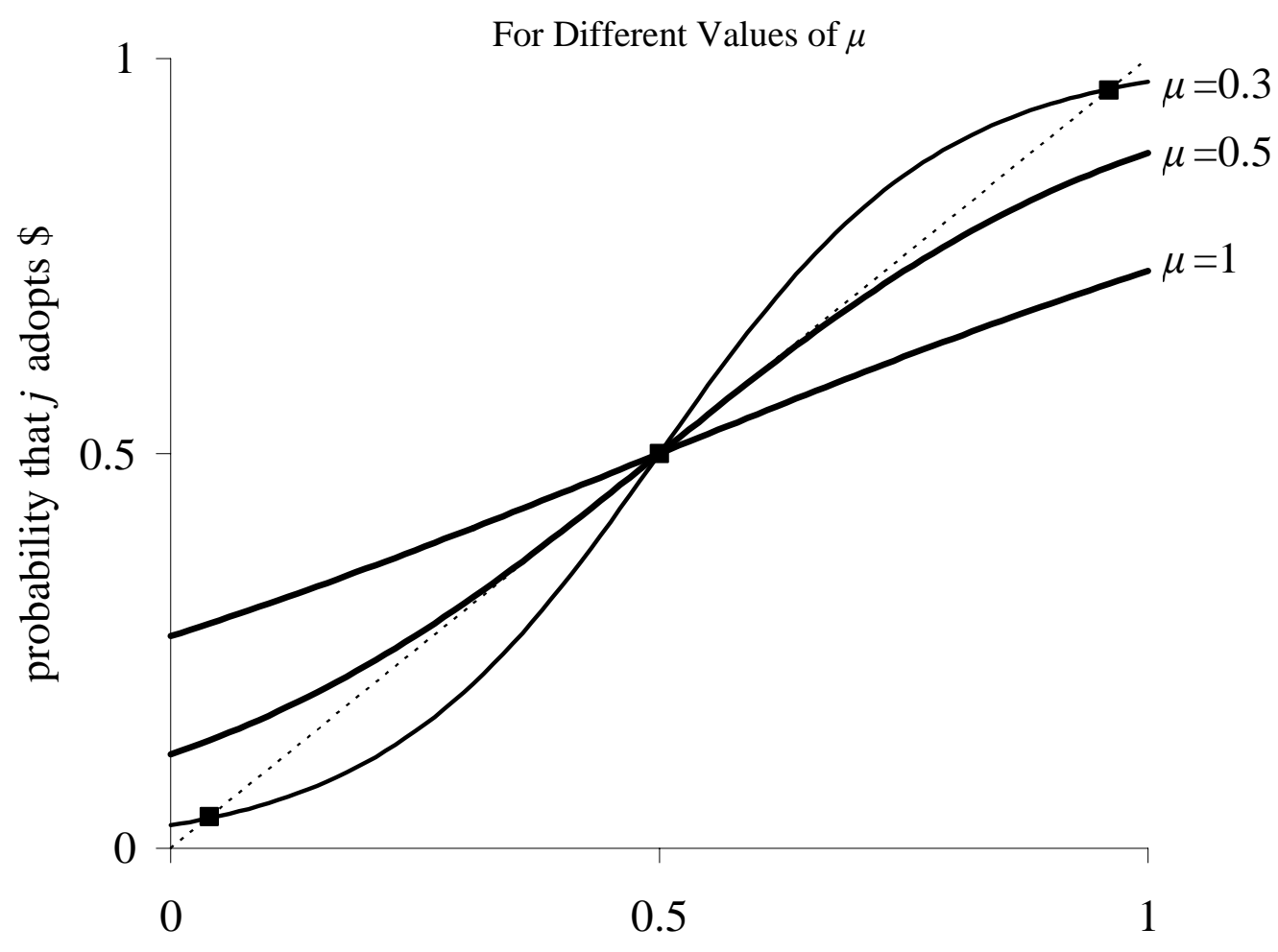

probability that $i$ adopts $\$$ 
Figure 7. Equilibria of the Stochastic Anchor Choice Model With Anchor-Specific Payoffs

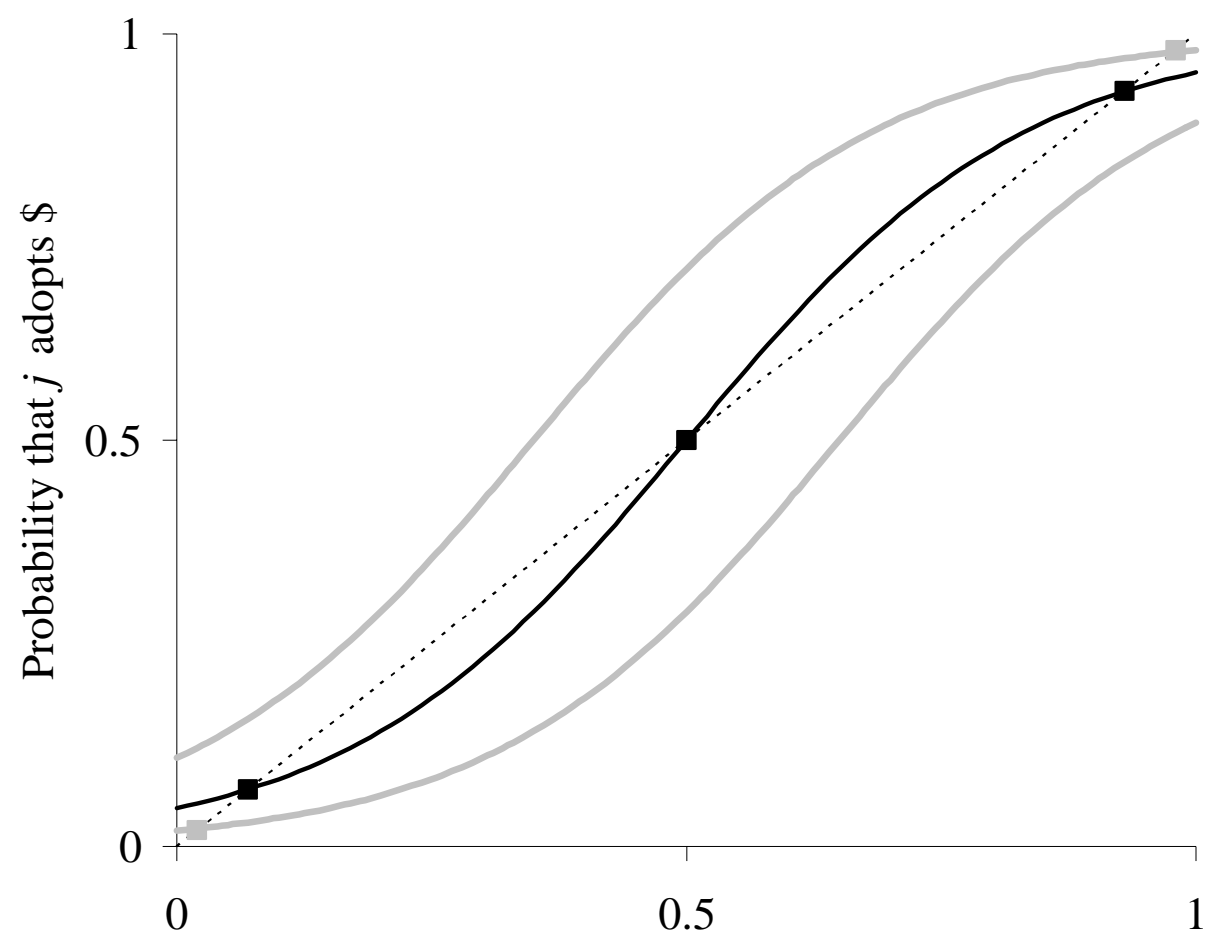

Probability that $i$ adopts $\$$

Figure 8. Actual and predicted number of dollar anchors, given $x$ percent of actual trade with the dollar bloc (all defecting to a mark anchor), 1990-1997

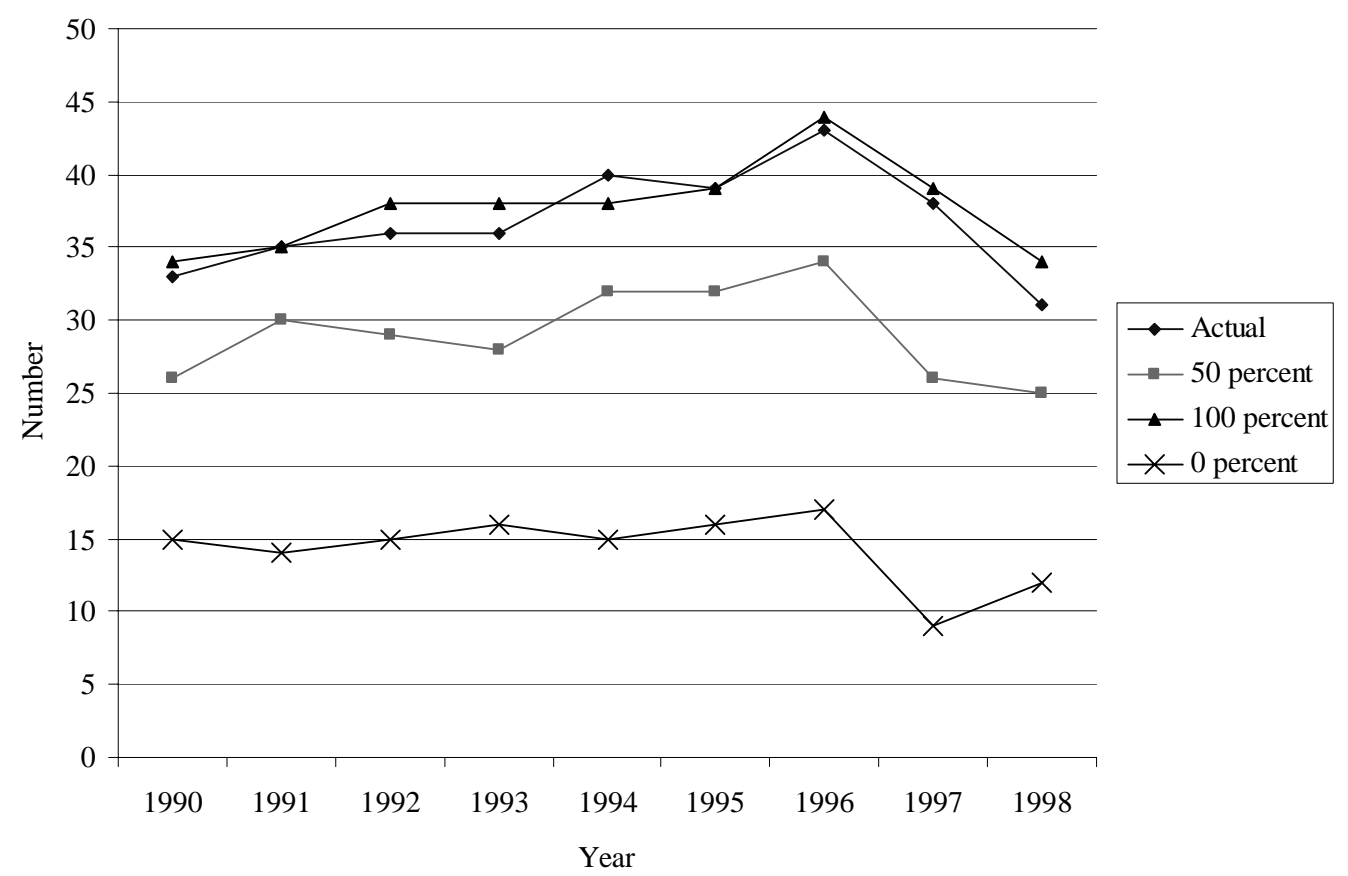

Note: A country is classified as being on a given regime if the predicted probability amongst all regimes is maximal. Also see text. 
Figure 9. Actual and predicted number of German mark anchors, given $x$ percent decrease of trade with the dollar bloc (all trade increases from dollar bloc defections are counted as trade with the dollar bloc), 1990-1997

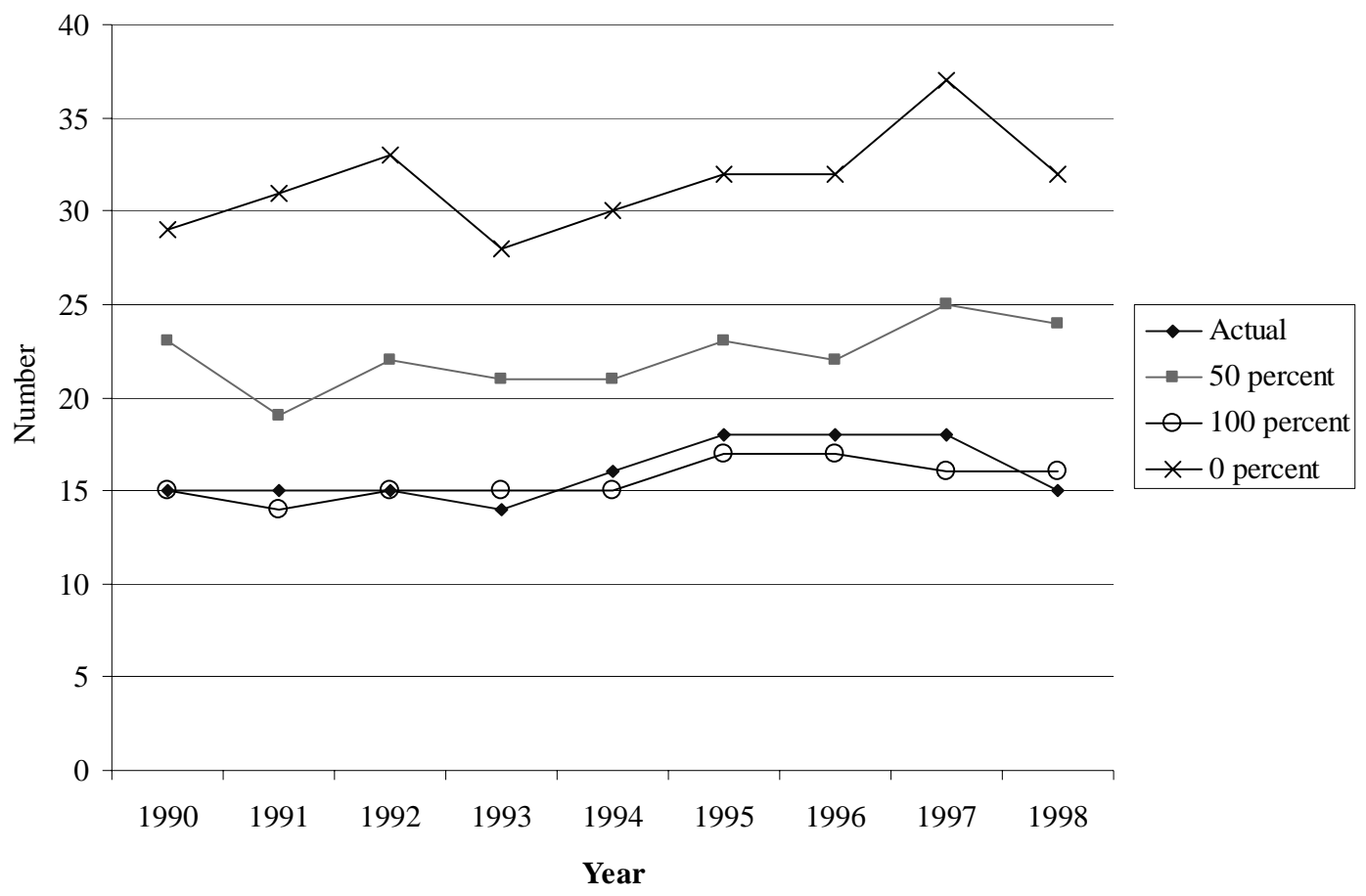

Note: A country is classified as being on a given regime if the predicted probability amongst all regimes is maximal. Also see text. 


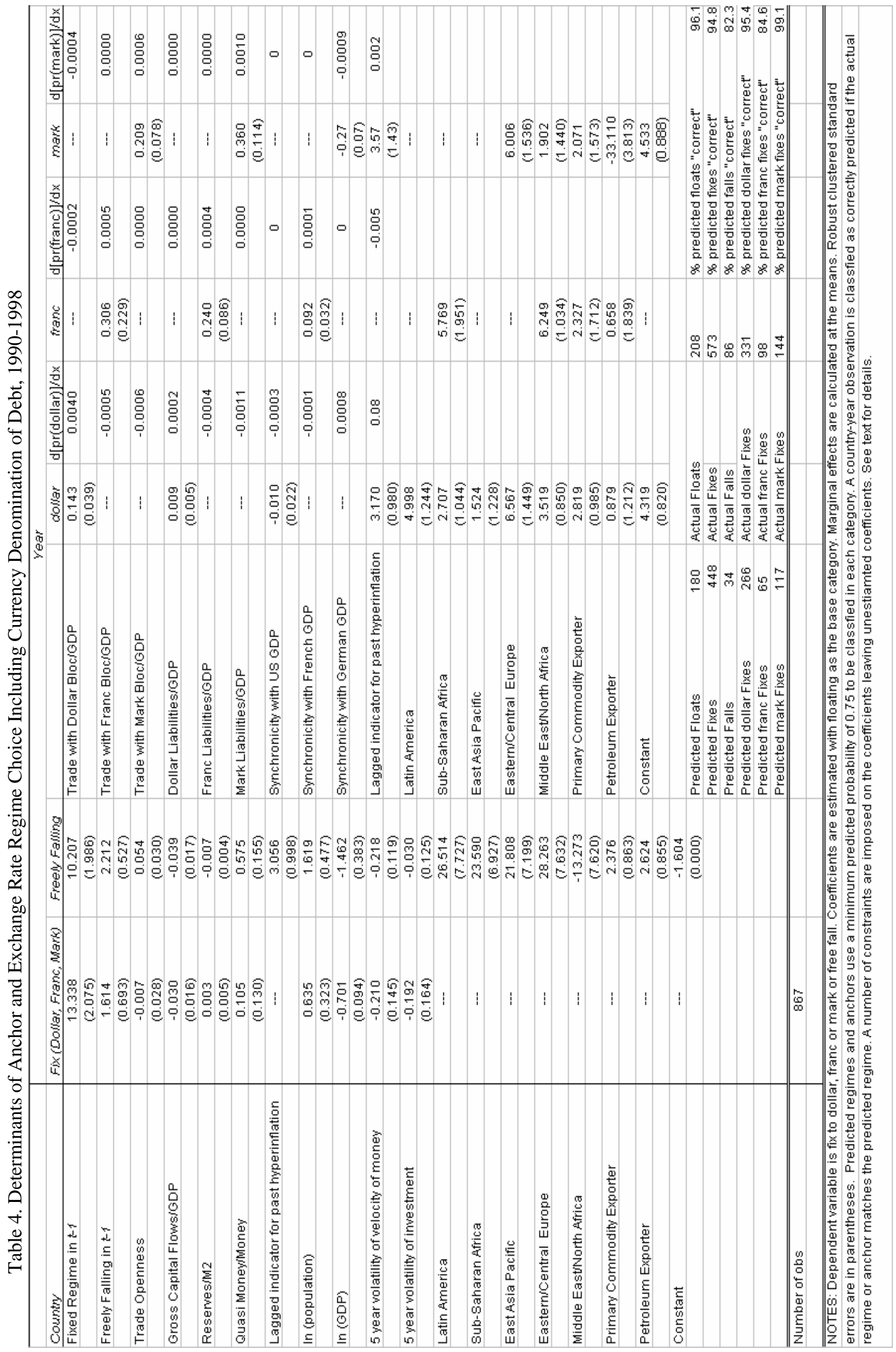




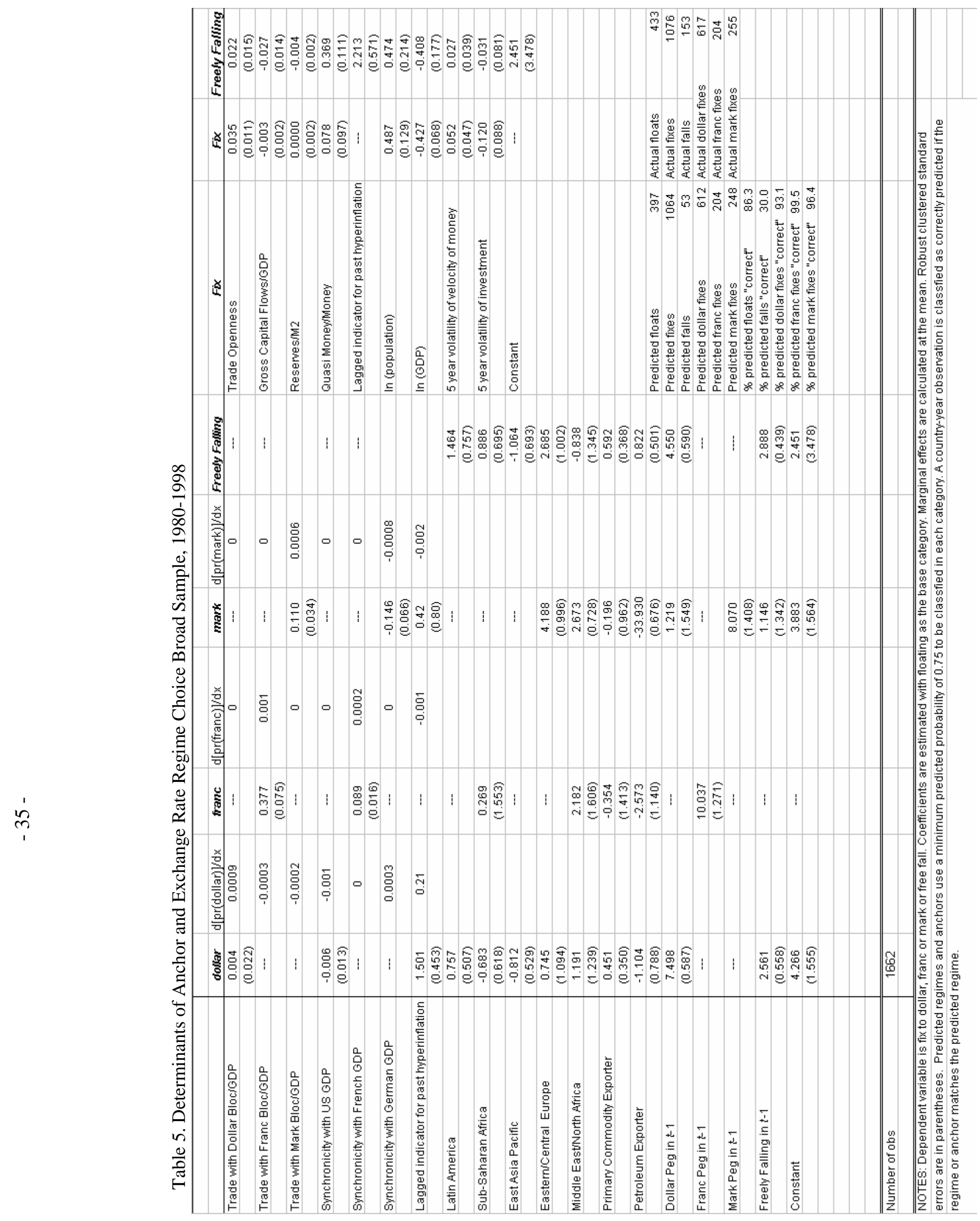

